FILOLOGIJA 71, Zagreb 2018.

UDK 821.163.42.08 Starčević, A. DOI https://dx.doi.org/10.21857/9e31lhn3xm Izvorni znanstveni članak Rukopis primljen 28. VIII. 2018. Prihvaćen za tisak 28. I. 2019

Ivan Marković

Odsjek za kroatistiku

Filozofski fakultet

Sveučilište u Zagrebu

Ivana Lučića 3, HR-10000 Zagreb

ivan.markovic@yahoo.com

\title{
BILJEŠKE O JEZIKU ANTE STARČEVIĆA
}

Jezik Ante Starčevića (1823-1896), izrazito važna hrvatskoga političara i pisca, još su suvremenici smatrali "osebujnim" (Mihovil Pavlinović). Međutim jezikoslovci do danas gotovo ništa relevantno o toj osebujnosti nisu rekli osim činjenice da je od 1850. Starčević dosljedno pisao ekavštinom. U ovome radu uočava se i raščlanjuje nekoliko odlika Starčevićeva jezika prema kojima je on Starčevićevim suvremenicima doista mogao biti "osebujan". To su (1) irealna kondicionalna rečenica sa $d a+b u d e m$ + GPR, (2) anteriorna temporalna rečenica s veznicima kon što i nakon što, (3) prijedložna skupina u supor (+ DAT), (4), disjunktivno ali te (5) futur sa budem + INF.

I. Što god mi o numizmatici, o urbanizmu i o pučkom imaginariju mislili, onaj čiji portret krasi najveću hrvatsku banknotu, hiljadarku, onaj kojemu Hrvati novcem iz vlastita džepa sagradiše dom, zapravo palaču usred Zagreba (1894), i kojega u smiraj njegova života prozvaše Ocem Domovine, točnije Evgenij Kumičić svoju je Urotu zrinsko-frankopansku posvetio »otcu otačbine« (v. EK 1893; 1895), taj dakle mora da je velik hrvatski muž. Ante Starčević to doista jest. No unatoč tomu i unatoč njegovu zamašnu publicističkom i književnom opusu jezikoslovna je kroatistika Starčevićevu jeziku dala malo prostora. U ovome će se radu probrati nešto upadljivih gramatičkih odlika Starčevićeva jezika i pokušati razvidjeti u čemu je on zapravo u drugoj polovici 19. stoljeća - ako uopće jest bio osebujan. Odabrani istraženi korpus obuhvaća tridesetak što kraćih, što dužih, što publicističkih, što proznih, što političkih tekstova i govora objavljenih od 1845. do 1890. (v. Vrela), načelno u obliku u kojem su prvi put objavljeni, tj. kako ih je bio priredio sam pisac, što nije uvijek jedno 
te isto, o čemu će također biti riječi. Kako je naše čitanje odabrana korpusa bilo odmicalo, tako nam je sve jasnije postajalo da ponajviše uočavamo veznike i perifrastične glagolske oblike, pa ćemo dobar dio rada posvetiti njima (v. § IV). Uvodno ćemo dati nužne obavijesti o Starčevićevoj jezičnoj biografiji i mijenama (v. § II) te o dosadanjem filološkom pristupu njegovu djelu i jeziku, koji je, vidjet ćemo, bio dosta površan (v. § III). Pri kraju rada naznačit ćemo moguće daljnje zadatke u pristupu Starčevićevu jeziku (v. §§ V-VI) te sabrati do čega smo u ovome radu došli (v. § VII).

II. Ante Starčević (23. V. 1823-28. II. 1896) ${ }^{1}$ rođen je u Velikom Žitniku kod Gospića, lička korjenika, sam za sebe reče: »rodjen štokavski ikavac« (AS 1851c:695), »u zadrugi rodjen i uzgojen do koje 15. godine, ja se onoga stanja, i narave zadružna života još najbolje setjam« (AS 1888:3).

II.1 Vojna granica pod upravom je Beča, njemačku pučku školu Starčević od 1830. pohađa u okružnome središtu Klancu. Bratić Antina oca, karlobaški župnik Šime Starčević, pisac gramatike (1812) i snažan zagovornik štokavske ikavštine, 1836. vodi ga sa sobom u Bag (Karlobag). Ante kod Šime i kod župnika Jose Vlatkovića, župnika u Smiljanu, privatno polaže prva dva razreda gimnazije. Na gimnaziju u Zagreb odlazi 1839. Ostala je zabilježena anegdota s prijamnog ispita iz latinskoga: profesor Klemenić pita ga da prevede kajkavske rečenice na latinski, Starčević ne razumije ni riječi pa mu pripomogne profesor Antun Mažuranić pitajući ga štokavski. Kajkavski Zagreb, dakako, tih godina tek postaje žarište ilirizma i zagovora štokavske jekavštine. Kao gimnazijalac Starčević susreće preporodne prvake, profesore Antuna i Ivana Mažuranića te Ljudevita Gaja, 1840. gleda Jurana i Sofiu, prvu kazališnu predstavu na hrvatskome, upoznaje šulkolegu Eugena Kvaternika. Filozofiju na zagrebačkoj Akademiji studira 1843-1845, objavljuje prve radove u Danici, po završetku studija vlada latinskim, grčkim, njemačkim, mađarskim, talijanskim, poslije francuskim. Ljeta 1845. u dogovoru sa Šimom Starčevićem i senjskim biskupom Mirkom Ožegovićem odluči poći u Peštu na bogosloviju, prije polaska bude još u Zagrebu svjedok krvoprolića 29. VII. 1845. (tzv. srpanjske žrtve), upravo i sam jedva izvuče živu glavu. U Pešti se - u kojoj tada studiraju i Eugen Kvaternik i Adolfo Veber - više zanima filozofijom i poviješću, filozofiju doktorira već 1846, teologiju razvlači i nakraju ju ne završava, polemičan i tvrdoglav napušta svećenstvo i 1848. vraća se u Zagreb. Natječe se za upražnjeno mjesto na katedri za filozofiju zagrebačke Akademije, mjesto ne dobiva, čini se intervencijom biskupa Ožegovića (doduše 1850. stara je Filozofija ionako ukinuta). Zapošljava se u odvjet-

1 Opširne životopise A. Starčevića kojima smo se služili dali su Šegvić (1911), Drechsler (1912), Horvat (1940), Jelčić (1995). 
ničkoj pisarnici Lavoslava Šrama. Za apsolutizma 1850-ih intenzivno piše, tada je možda najplodniji hrvatski pisac. Po restauraciji županija i parlamentarizma 1861. bude izabran velikim bilježnikom Riječke županije (veliki bilježnik najviši je županijski činovnik), čime počinje njegova politička karijera. Iste godine izabran je u Sabor (u kotaru hreljinsko-grobničkome), 1863. prvi put zaglavi u zatvoru zbog županijskih predstavaka koje je bio pisao (drugi će put biti 1871. zbog sumnje da je imao veze s Rakovičkom bunom), od 1865. redovito je biran u Sabor kao zastupnik različitih kotara. Od 1839. do smrti 1896. živio je uglavnom u Zagrebu, s nekoliko izbivanja - Pešta (1845-1848), Rijeka (1861-1865), Jastrebarsko (1871, kod sinovca Davida), Sušak (1879-1884). Prepričano dijalektološki i lingvistički, Starčević je ruralni štokavac ikavac koji je mnogo vremena proveo među urbanim kajkavcima i čakavcima, $\mathrm{k}$ tomu poznavao je klasične i moderne europske jezike, u zemlji u kojoj od 1840-ih jezik uprave, knjige i školstva postaje štokavska jekavština.

II.2 Prevratne godine u Monarhiji i dobru dijelu Europe (1848-1849) na nekoliko su načina prevratne privatno Anti Starčeviću, koji tada - uočimo to - ima 25 godina. Prvo, po povratku iz Pešte nije dobio mjesto na zagrebačkoj Akademiji; da jest, moguće bi do kraja života ostao gimnazijski profesor, kako se manje-više dogodilo Vjekoslavu Babukiću ili Antunu Mažuraniću. Drugo, biografi redovito prepričavaju događaj s Velike Gospe u Klancu 1848. kad se upoznavši graničara bez obiju ruku - odsječenih mu po kazni - iz prve ruke osvjedočio $u$ to da Hrvatima nema sreće ne samo s Peštom nego ni s Bečom; ta spoznaja učvrstit će se poslije Jelačićeve obrane Austrije te za apsolutizma 1850-ih. Treće, Starčević zarana uviđa da je ilirska ideja ujedinjenja Južnih Slavena propala te da se u Srbâ pod krinkom jezičnog ujedinjenja javljaju neskrivene i Hrvatima neprihvatljive političke sklonosti, koje hrvatska inteligencija nije jasno uočavala, a iskazivane su više nego očito u Karadžićevu spisu "Srbi svi i svuda" (1849); podsjetimo, s tim istim Karadžićem petorica hrvatskih poslanika sljedeće godine (28. III. 1850) potpisuju književni dogovor o zajedničkome jeziku (v. Bečki dogovor 1850), prihvativši barem na papiru ono za što se Karadžić bio zalagao. K tomu Lj. Gaj negdje odmah u svibnju 1850. Starčeviću povjeri priređivanje prijepisa glagoljičkoga Istarskoga razvoda iz 1325. godine, preko čega se ovaj izravno upoznaje sa starim hrvatskim spomenicima i jezikom. Sve to raspalilo je Starčevićevu polemičnost i pomoglo mu da izoštri svoje jezične stavove te izgradi - danas bismo tako rekli - sasvim odjelit idiolekt. Slijedi nekoliko riječi o tome. Najkraće moguće rečeno: dok se hrvatska inteligencija iscrpljivala u lutanjima i traženjima oko ilirstva, južnoslavenstva, hrvatsko-srpskoga približavanja, Starčević je 1850. - nekoliko de- 
setljeća prije sviju - prozreo budućnost i bez krzmanja otvoreno počeo govoriti o hrvatskome jeziku i tome kako bi on imao izgledati. ${ }^{2}$ Pritom vječito valja imati na umu što su pojedini od nazivaka u svoje doba mogli podrazumijevati i kako se na njih moglo gledati, ili kako je to Starčević u Nekolikim uspomenama formulirao (isticanje naše):

Za Ilirstva nebiaše druga nego da budeš Ilir ili Magjaron. Reći da si Hervat, znamenova da si Magjaron. [...] Samo u tu jednu stranku, u Ilire ili u Magjarone, morao je kod nas svatko spadati. O redkih koji se braniše proti tomu razredjivanju ljudih, ili nehtedoše u nijedan taj razred brojeni biti, o tih biaše sud da su habi-kruhi, prosvetljeni zvahu ih fruges consumere nati, a javno mnenje govoraše skladno, da su austrianski špioni. (AS 1870:1)

II.3 Prve svoje radove - pjesme i napis o pirnim običajima u Lici - Starčević objavljuje 1845. u zagrebačkoj Danici i novosadskoj Bačkoj vili (Jurišić 1943:541) te potom 1846. u zadarskoj Zori Dalmatinskoj, 1848. opet u Danici (Jurišić 1943; Jelčić 1995) te u opozicijskome Slavenskom Jugu (Horvat 1940:88-92). Svi ti radovi pisani su "ilirskim" jezikom i slovopisom, dakle jekavski, s različitim bilježenjem jata, bilo sa $\langle i e\rangle$ i $\langle j e\rangle$ bilo sa $\left\langle\right.$ ě.$^{3}$ Jekavski će Starčević objavljivati i poslije, no prema svemu sudeći ili uredničkom odlukom ili dogovorno s urednikom. Tako primjerice u Narodnim novinama (npr. AS 1851a; 1851b), u Nevenu (npr. AS 1853), u Pozoru (npr. AS 1860), čak u Zvekanu, pravaškome satiričkom listu (npr. AS 1867a; 1867d). ${ }^{4}$ Međutim posve je jasno da 1850. Starčević ne samo da prelazi na ekavštinu nego bistri i javno iznosi vlastitu jezičnu koncepciju, drugačiju i od ondašnje zagrebačke, i od ondašnje zadarske, i od ondašnje karadžićevske. Prvo ju je iznio u "Predgovoru" Istarskomu razvodu (AS 1850 [1852]), koji je u Kukuljevićevu Arkivu objavljen 1852. godine, ali datiran je 18. VII. 1850. pa ćemo s njime započeti.

"Predgovor" Razvodu istrianskomu od god. 1325. važan je zbog nekoliko razloga. Prvo, pisan je ekavštinom. Urednik Ivan Kukuljević popratio ga

2 Kako to M. Pavlinović reče: „Starčević je najbolje pogodio, kad je kroz pometnje preranog jugoslavenstva i mimo krparije srbo-hrvatstva, iznio zastavu hrvatstva. Te mu zasluge nitko neporeče« (MP 1884:26).

3 Usp. također Moguš (1997), Samardžija (2017). Članak "Iz Like" u Slavenskome Jugu osim Horvata (1940) drugi biografi ne spominju, a prema opsežnu odlomku pisan je jekavski. Smatramo to pouzdanim jer Horvat za razliku od drugih dvadesetostoljetnih priređivača Starčevićev jezik nije preinačivao.

4 Anonimni dijalog "Stekliš i prostodušnik" (AS 1867a) objavljen je kao zasebna autorska knjiga Bi-li k Slavstvu ili ka Hrvatstou? (AS 1867b), također jekavski, eda bi tek 1894. u sabranim Djelima (AS 1867c [1894]) osvanuo u, pretpostavljamo, izvornom obliku - ekavski. Anonimni dijalog “Oklad” objavljen je u Zvekanu jekavski (AS 1867d), eda bi poslije postao ekavski "Uvod" u Pisma Magjarolacah, koja su sva ekavska (AS 1879). 
je fusnotom u kojoj je rekao sljedeće:

$\mathrm{Na}$ želju Gosp. Dr. Starčevića zadržali smo u tom predgovoru i u njegovih razjasnenjih velevažnog ovog članka, onaj pravopis kojim se rečeni Gospodin služi. Op. Ur. (AS 1850 [1852:227])

Koliko znamo mi i literatura o Starčeviću (v. Literaturu), to je prvi Starčevićev tekst na ekavštini. Doduše omaklo se u njemu nekoliko rogatih e-ova, tako cěli (str. 228), stólétja (229), trěba, uvěk (230), potrěbe, rěčostovci (231, sic!, umj. rěčoslovci), rěč, město (268-271, uz reč, mesto). Drugo, Starčević u njem jasno utvrđuje zašto je Razvod tako važan hrvatskomu jeziku:

Spomenik ovaj nije samo zato zlamenit, što se iz njega jasno vidi, da je kod otaca naših, jezik hervatski bio sasvim služben, a ne samo služben nego i diplomatički, - još onda, kad mnogi zapadni narodi nisu ni mislili, da bi svoj na to veličanstveno mesto uzneli, premda, velim, on dokažuje, koliko je bio kod otacah naših hervatski narodni ponos, kome kod nas ni traga neima; itako, on je najzlamenitii s toga, što nas spominje na mnoga, još puno staria, diplomatička pisma, sastavljena u hervatskom jeziku, kako se iz ovoga vidi, puno čistiem, nego li su pisma mnogih naših današnjih pisacah. (AS 1850 [1852:227-228])

Starčeviću je dakle kao dan jasno da se njemu suvremeni hrvatski jezik ima na što osloniti i da to nije samo renesansna i barokna dalmatinska književnost u koju su se preporoditelji ugledali nego i mnogo starija diplomatička građa. ${ }^{5}$ Treće, Starčević uočava razlike među čakavštinom, kajkavštinom i štokavštinom, i vapi za jednim jezikom za sve Hrvate. Ne časeći Starčević ga je sam počeo izgrađivati i opisivati, a javno deklarirati u prikazima časopisâ te polemikama s Andrijom T. Brlićem i srpskim novinama koje 1851. i 1852. objavljuje u Narodnim novinama. ${ }^{6} \mathrm{U}$ tim napisima Starčević oštro, zapravo na rubu prostaštva ili prešavši taj rub, polemizira s prevladavajućim jezičnim koncepcijama, ponajprije karadžićevskom, tj. onom koja je dogovorena u Beču 1850.7

Tako već 3. X. 1851. u prikazu Kola urednika A. T. Brlića piše da »neimamo podpunu gramatiku«, da je jezik Kola »ovako bljutav, ovako tvèrd i ne-

5 Podsjetimo, hrvatski je diplomatičkim u Hrvatskome saboru proglašen dana 23. X. 1847.

6 Polemika sa srpskim novinama začela se zbog toga što je Matica ilirska bila dala Anti Kuzmaniću da s njemačkoga prevede knjigu Das Buch der Natur Friedricha Schoedlera; srpskim je novinama (Serbski dnevnik) bilo neprihvatljivo da Matica ilirska taj posao povjerava prvaku zadarskog ikavskog kruga (v. npr. Vince 1978 [2002:298301]).

7 Budući da nas zanima A. Starčević, u odjeljku koji slijedi ne možemo i nećemo spominjati sve rukavce jezičnih polemika iz sredine 19. stoljeća; njihov detaljan pregled dao je prije svega Vince (1978 [2002]). 
ugladjen«, da je tu ispušten »svaki samoglasac ispred $r$ « (što će ubuduće biti Starčevićev lajtmotiv), da su to »blejanja, štekćanja i hèrcanja « (blejanje mu je poslije sinonim za jekavštinu ili ijekavštinu, tj. blekavštinu, v. npr. AS 1852b:603; 1871a:2), najzad objavljuje svoje »riečoslovno načelo«, s jasnom stočarskom aluzijom, koju će poslije razrađivati:

Piscu netreba gledati, kako koji govedar govori, nego mu se valja tèrsiti, da ga svaki govedar razumi, $i$ da uho slušatelja nevredja. (AS 1851a:654)

U prikazu Dubrovnika 7. X. 1851. još uvijek govori »mi Iliri, Jugoslaveni, kako li ćemo se jednim imenom zvati«, ali ne propušta spomenuti različito bilježenje jata i ispuštanje »samoglasca pred $r$ «te »niekakve kline« umjesto $h$ u genitivu plurala, tj. »II. sklonu višebroja« (AS 1851b:662).

Najzad 17. i 21. X. 1851. u odgovoru A. T. Brliću opširnije razlaže svoju jezičnu koncepciju, ponajprije ponavlja svoje »rečoslovno načelo«:

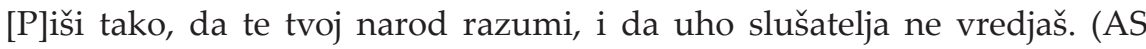
1851c:694)

Ono prethodi Babukićevu »Govori za uši, a piši za oči« $(1854: 9,431)$, a izravno je suprotstavljeno Karadžićevu, koje u Starčevićevoj stočarskoj parafrazi glasi ovako:

Oni vele: piši kako i govoriš. Rabbi scholae veli, da se treba jezik učiti od govedarah i svinjarah. [...] Oni, koji ga kèrpaju i vele: piši kako pravo govoriš, idu s konja na magarca; jer se baš to pita: ko govori pravo? - Rabbi veli, da najbolje govore svinjari i njihovi drugovi kozari itd. (AS 1851c:694)

Potom u trima točkama razlaže »kako te stvari stoje« jasno razlikujući govoreni od pisanoga jezika, pismo i izgovor, te ponovo istaknuvši lajtmotiv - vokal ispred slogotvornoga [r]:

Kod izpusćanja samoglasca pred $r$ škola ova gledala je samo, da pravo rečem, na svoje selo: u govoru ne spaziše samoglasac, pa ga izpustiše, jer ga izpusća i narod, quod erat demonstrandum. (AS 1851c:694)

$\mathrm{Na}$ kraju se Starčević posve ogolio i založio za »polepšavanje našega jezika « u ekavštini. Pristup mu je pritom diletantsko estetski, ali držat će ga se zagriženo do kraja svojega života:

U našem jeziku nije ni jedna reč, koja bi imala više od pet slovkah, a uz šaranje jednoslovična ih reč toliko ima, n.p. iz lep ali bel postaje lijepijema, bijelijema itd. - samo ako se dosledno piše. To je srednja perioda!! - Meni ovde druga neostaje, nego uzeti ali čisti $i$ ali $e$. Ja sam rodjen štokavski ikavac, dakle niko nemože mi reći: Cicero pro domo sua [...] - velim: ovo je (i) najpotištenii, najgadnii glas, koi samo nekoliko nas štokavacah razumi. Ja sam dakle za čisti $e$. I zbilja, on je najlepši glas, koi svi razumimo. [...] Ovako mi imamo jezik, kome se isti talianski mora duboko klanjati, a drugačie, kroz blejanje (ije, itd.), rokćanje (izpusćanje e pred r) i hakanje (izgovaranje nad- 
glaska - ne slova - jer ga i neimamo - h) postaje nam naš jezik puno gadniim od ikojega drugoga. (AS 1851c:695)

Uzgred je još spomenuta i napredujuća gramatika, o kojoj se i Uredništvo Novina oglasilo u fusnoti. Na Rečoslovici je Starčević ozbiljno radio i već 6. XII. 1851. u Novinama objavio poziv na pretplatu. Da se tko ne bi našao iznenađen njezinim sadržajem, »da se nebi ko poslie kajao«, ponovio je svoje »rečoslovno načelo«:

Govori i piši razumljivo, a uz to, koliko je moguće, uho ugodno. (AS 1851d:802)

Premda u naslovu poziva stoji »hervatska rečoslovica«, $\mathrm{u}$ tekstu se hrvatski ne spominje, naprotiv spominju se »na jugu živući Slavjani«i nastojanje k sjedinjenju »u jeziku književnom; ali se baš u tome dan na dan jače razstajemo«. Od Rečoslovice međutim nakraju nije bilo ništa, naprotiv 1854. u Književnoj prilozi k »Nevenu "Starčević je "Izjavljenjem" pretplatnicima morao objasniti što je s njom, zašto ju nije uspio dogotoviti i ponovo zalud obećao da će izići »još ove godine« (AS 1854:XXXVI). Izišla nije nikad. Drechsler će pretpostavljajući filozofijsku njezinu osnovu i okretanje sintaksi poslije odrješito napisati: »Ovakva Starčevićeva gramatika bila bi svakako daleko viša od primitivne gramatike Babukićeve, koja gotovo i nije došla dalje od paradigama, pače bila bi znatnija i originalnija od inače dobrih [...], što ih je napisao Antun Mažuranić« (1912:396).

III. Starčević je sasvim sigurno bio svjestan da njegov jezik i pravopis (upravo slovopis) otklanjaju od uzusa, odnosno s vremenom je to morao postati. Svijest o otklonu izbija na vidjelo i iz njegovih tekstova, bilo programatskih poput napisa "Jezik i pismo Hervatah" iz 1871. u prvome broju pravaških novina Hervatska, u kojemu ponavlja osnovne stavove i to da »narod hervatski ima svoje narodno, osamstogodišnje knjižtvo« (AS 1871a:2), bilo autoironičnih, poput proslova "Na štioca" u Pismima Magjarolacah, gdje će replikom reći ovako (isticanje naše):

Obazirimo se na politiku. Misliš-li da pišuć o tom, i pravopisom kojim se nitko nesluži, budemo dobiti čitateljah, i primamiti Slavoserbah, za-da se uče i poprave? (AS 1879:V)

Potom nastaviti po starim, skoro trideset godina starim lajtmotivima (isticanje naše):

Što se tiče načina pisanja, jezika, izgovaranja, ja se deržim, koliko znam i mogu, naše osamstogodišnje knjige, i s te brazde nebudem nikada krenuti. Osvedočen sam da Slavoserbi bez razloga nerokću i nebleje; da su oni na to primorani; da je sverha njihovu poslu nagerditi i time omraziti hervatski jezik; da njihova čerčkanja, bez obzira na drugo, nemože izgovarat ni Nemac, toliki neotesanac. (AS 1879:VII-VIII) 
Starčevićeve odjelitosti i tvrdoglavosti svakako su bili svjesni i njegovi suvremenici. Stanislav Šimić (1936:74) prenosi mišljenje Starčeviću po mnogočemu zapravo bliska Mihovila Pavlinovića (1831-1887), tek što nije naveo odakle ga je preuzeo. Riječ je o Pavlinovićevu napisu "Zasukanost naučanstva (Starčević)",, šestome odjeljku Hrvatskih razmišljaja (isticanje naše):

Odavna se odtisnuo od živa naroda; baciv se, kad u kajkavce, kad u čakavce; po svom osebunjstvu preziruć cio noviji napredak hrvatske knjige, Ante ne samo da misli nego i govori i piše, kako to on sam zna misliti, govoriti i pisati. A to jamačno neće ostati uzorom ni razborna mišljenja ni bistra pisanja. Njegovo samo pero hvata živu živcatu sliku Antina Ja: Le style c'est l'homme. (MP 1884:27)

Pavlinoviću ćemo se još vratiti (v. dalje § IV.6), zasad nam je važno njegovo "osebunjstvo", koje će obilježiti filološku percepciju i recepciju Ante Starčevića, i to sve redom na pogrešan način. Evo kako. Prvo, priređivači su Starčevićev jezik mijenjali. Krajem 19. stoljeća Stranka prava priređivala je Djela Ante Starčevića, ali nije ih dovršila. ${ }^{9}$ To je valjda bilo i do danas ostalo jedino nepatvoreno ozbiljno izdanje. Starčevićev je jezik poslije jekaviziran i pravopisno mijenjan (tako Jurišić 1943), jekaviziran, pravopisno i gramatički mijenjan (tako Ladan 1971), a kad su se napokon stekli sociolingvistički uvjeti za to da se Starčević opet objavi u izvornom obliku, to je učinjeno (tako Jelčić 1995), ali opet nevaljalo, u skladu s načelima Matičine edicije Stoljeća hrvatske književnosti, pa ćemo tako ondje naći oblike tuđin (str. 78), đak (166) i luđak (300) - koje da je prema tomu Starčević napisao 1845, 1852. i 1879. - a znamo da ih 1845. i 1852. nije mogao napisati (slovo $\langle\mathrm{d}\rangle$ uvedeno je u grafiju JAZU tek 1878), a 1879. nije htio napisati, odnosno gotovo pouzdano možemo reći da Starčević slovo $\langle\mathrm{d}\rangle$ nije napisao nikad (v. o tome dalje § VI).

Drugo, od mantre "osebujnosti" filologija se u pristupu Starčeviću nije mnogo odmakla, tj. sve o čemu su filolozi obljetnički pisali bili su Starčevićeva notorna ekavština (npr. Moguš 1997; Samardžija 2017) te "osebujan" stil i retorika (npr. Drechsler 1912; Ladan 1971; Vince 1978 [2002:484]; Jel-

8 Naučanstvo je doktrinarizam, jedan od hrvatskih političkih pravaca druge polovice 19. stoljeća kako ih Pavlinović razlučuje (1884): umišljenstvo ili idealizam (J. J. Strossmayer), tvarstvo ili materializam (L. Rauch), razborstvo ili prakticizam (I. Mažuranić) te naučanstvo ili doktrinarizam (A. Starčević), pa k tomu još njemačko sredinjaštvo ili centralizam te sva sila pogrdnih izraza za politiku L. Pejačevića i K. Khuen-Hédervárya, primjerice spahinstvo.

9 Izdavački odbor činili su Fran Folnegović, Gjuro Jakčin, Mile Starčević, Josip Frank, Evgenij Kumičić i Mijo Tkalčić; Djela su u reprintu objavljena i dopunjena 1995, a njihovi dijelovi još u nekim edicijama. 
čić 1995; Sabljak 1997; Slavić 2017), koje su se dohvaćali i nefilolozi (npr. Šimić 1936; Barišić 1994).${ }^{10}$ Koga bude zanimalo, može provjeriti, u svakom od tih radova naići će na atribut osebujan.

Treće, koliko nam je poznato, samo su Jurišić (1943:552-553) i potom Bratulić (1995:483-484) svaki na svoj način pobrojili po rukovet doista jezičnih Starčevićevih odlika. No s razumljivim metodološkim nedostatkom - među "osebujnim" odlikama Starčevićeva jezika našle su se kako one koje doista jesu Starčevićeve (samo pitanje je može li se to bez temeljite kontrastivne analize znati) tako one koje ni po čemu nisu samo Starčevićeve, nego jednostavno pripadaju odlikama jezika zagrebačke filološke škole, tj. onodobnomu književnomu jeziku. Ako je Starčević u tom smislu i u čemu bio osebujan, onda je to njegovanje jezika zagrebačke filološke škole - primjerice tzv. starih pluralnih padeža, koji uvijek prvi padnu na pamet - sve do 1890-ih, kad je to doista moglo biti pomalo zastarjelo, jer nove pluralne oblike nalazimo u Narodnim novinama već 1850 -ih. Tako primjerice Uredništvo Narodnih novina u bilješci uz Starčevićev poziv k pretplati na Rečoslovicu (AS 1851d) ima dative plurala čitateljima, književnicima, Kajkavcima i lokative plurala pravopisima, nariečjima. Za takve oblike Babukić u gramatici piše da ih »věšto uho nipošto podněti nemože; jer su prava monotonia (jednoglasje), te $\mathrm{k}$ otomu jošte směraju na osiromašenje oblikah padežah « (1854:183). Kako međutim vidimo, u Novinama ih unatoč Babukiću ima. - Da, ali u Starčevića ih nema ni 1890, nego nahodimo dative plurala vlastnikom, ljudem i lokative plurala $u$ spisih, o posedih (AS 1890:3-4), a to je već važna filološka spoznaja. Ili, da je slogotvorno [r] dokraja pisao dvoslovom 〈er〉, to je znak Starčevićeve ustrajnosti samo po sebi, ali važnije je to da je popratni vokal - možemo to zaključiti iz onoga što je pisao (v. § II.3) - najvjerojatnije i izgovarao, što je suvremenicima moralo zvučati usiljeno. Ili, da je genitiv plurala dokraja pisao "ahavački", a lokativ plurala "ihavački", i to je znak ustrajnosti; tvrdoglav, hirovit i stekliš kakav je bio $^{11}$ - ovo je puka spekulacija bez ikakve potvrde - možda je krajnje $\langle\mathrm{h}\rangle$ čak i izgovarao, premda znamo da ga ni ahavci sami izgovarali nisu (v. Tafra 1995). Ili, da redovito ima kauzalni (uzročni) veznik bo, to za sjevernu Hrvatsku 19. stoljeća nipošto nije neobično. Valja nam dakle razlučiti ono što je neutralan hrvatski književni jezik druge polovice 19. stoljeća od onoga što pripada Starčevićevu idiolektu.

IV. Što ovim radom i posebno ovim odjeljkom želimo? - Želimo izdvo-

10 Ovamo možemo pridružiti i povjesničarsko očište i analizu pojmovlja danu u Holjevac (1999).

11 »Golem, neotesan, odsječit, zapne ti za oko netom ga prvom sretneš. Uz velika nehajnika za ljude, vidiš čovjeka sama sobom zadovoljna« (MP 1884:25). 
jiti nekoliko odlika Starčevićeva jezika prema kojima je on osebujan ne nama danas, nego prema kojima je on bio osebujan svojim suvremenicima - a da nije riječ samo o ekavštini - te eventualno pokušati uočiti neke njegove mijene kroz pet desetljeća pisanja. Naravno da nećemo zagrabiti cjelinu jezika, probrat ćemo što nam je pri radu na korpusu upadalo u oči. Za uvod samo još jedna opća formalna rečenica: sva isticanja u donesenim primjerima bit će naša.

IV.1 Kako uvodno rekosmo (v. § I), pri čitanju smo često uočavali veznike i perifrastične glagolske oblike, na njima najviše zastajkivali. Među njima se neintuitivnošću izrazito isticala kondicionalna rečenica s veznikom $d a$, svršenim prezentom budem i glagolskim pridjevom radnim (dalje GPR) ili bez njega. Stoga ćemo njome i započeti. Takvih smo rečenica u obrađenome korpusu pronašli stotinu i pedesetak, jednom riječju - mnoštvo. Prototipna bi bila primjerice ova:

Kako bi danas mi svi stajali, da budu Magjari tako učinili? (AS 1861c:32)

Neintuitivnost izlazi iz toga što $b u d u$, odnosno $b u d u+$ GPR u takvim rečenicama nema značenje budućnosti ili predbudućnosti, nego značenje koje bismo parafrazirali prošlosnim perfektom $s u+$ GPR, odnosno pluskvamperfektom su bili + GPR ili bijahu + GPR:

Kako bismo danas mi svi stajali da su Mađari tako učinili?

Kako bismo danas mi svi stajali da bijahu Mađari tako učinili?

Čini nam se da takvu inačicu u Starčevića ne nahodimo, tj. vrlo je dosljedan u svojoj sa budem. Kako od irealnih kondicionalnih rečenica očekujemo i danas (v. npr. Silić-Pranjković 2005:349), u apodozi redovito dolazi kondicional, u Starčevića često i kondicional II. (prošli), pa njihovim protazama pripisujemo značenje pretprošlosti, čak pretpretprošlosti. Ako se ne varamo, takvo značenje glagola budem izvan kondicionalnih rečenica s veznikom da u Starčevića ne nalazimo, nalazimo samo značenje budućnosti (v. dalje). Značenje pretprošlosti ili pretpretprošlosti jasno se vidi u ovome primjeru:

Da toga nebude [1] i nije [2], za premnoge nesreće nebi se bilo znalo [1'], i nebi se znalo [2']. (AS 1889:3)

Ako protaza da toga nije (2) ima apodozu u kondicionalu I. (2'), protaza da toga nebude (1) u apodozi mora imati "pomak" u kondicional II. (1') jer joj predikacija prethodi protazi (2). Ponovimo, ako se ne varamo, u Starčevića ne nalazimo kondicionalnu protazu da + sam (nisam, je, nije) + GPR.

Otprilike dvije trećine dotičnih rečenica imaju budem + GPR: ${ }^{12}$

12 Zbog zanimljivosti rečeničnoga tipa u ovome ćemo odjeljku primjera davati više, što će na svoj način pokazati njegovu plodnost i vremensku protežnost kroz sva 
Da budu kakovo pošteno dělo učinili, ti bi bio vidio na město one tučnjeda [sic!] se svi ljube, [...] (AS 1853:715)

Da bude ona uzpita o mojoj rečoslovici, iz Beča, izišavša u 23. broju ovogodišnjega »Nevena« samo dva meseca prie došla, ja joj se nebi bio ni oglasio. (AS 1854:XXXIV)

Da budem ja bio u onoj sednici, u kojoj no je zaključeno, da se taj odbor u Beč pošalje, ja bi se bio svom snagom opirao tomu zaključku, [...] (AS 1861b [1893:7])

Kako bi se bili imali ponašati Magjari, da budu ovo stanje poznali, i da im bude stajalo do slobode vlastite i naše? (AS 1861c:31)

Da bude koj austrianski sabor, na priliku Tirolski, ove ukaze odbio kakono smo ih mi odbili, onaj bi sabor doista bio u negacii. (AS 1866a:23)

Gledajmo Židove, Grke, Rimljane: da oni sami nebudu spisali svoju povjest, ili da im budu pisma propala, što bismo više znali o njih nego li o kakovu barbarskomu narodu? (AS 1867b:8)

Da nebudete onaj skok učinili, kako bi mi lahko bilo stegnuti vas pak vam kazati, [...] (AS 1867b:25)

Već god. 1848. bila bi se Austria razpala, da se nebudu Hervati za nju zauzeli. (AS 1870:27)

Da nebude Praiz potukao Austriu, mi bi danas spadali pod Beč, kako tamo spadaju i naša braća s preko Sutle. (AS 1871b:2)

Popi bo obijuh cerkavah, [...] i da budu hteli, ovakovi kakovi biahu i jesu, nebi bili mogli narod od gnjilenja na nijednu stranu pritegnuti. (AS 1876:25)

Da bude to znao Bátory, valjda bi bio zrelie promislio o ponudi časti »despota«. (AS 1876:56)

Da se nebudemo bojali da će oni biti jačji na šake, mi bi ga bili bacili iz gostionice. (AS 1879, I:12)

Ne znam što bi bio pregorio da mi nebude bilo biti tu. (AS 1879, I:52-53)

I Stekliš dojde gornjim Tuškancem. Da bude on prie pošao ili beržje išao, on bi me bio dostignuo. (AS 1879, I:150)

Bolje bi bilo da budemo mirovali. (AS 1879, I:169)

Stekliši kažu: da nebudu naši starii kuće sagradili, zemlje izkerčili, ogradili i obradili, mi danas nebi mogli živeti. (AS 1879, II:5)

Napoleon bi bio pognječio te cerve, da nebude bilo domaćih što kukavacah, što izdajicah: Slavoserbah. (AS 1889: 66)

Rečenice s protazom bez GPR, tj. s imenskim predikatom - ponajprije genitivnom ili prijedložnom skupinom - čine nekakvu četvrtinu potvrda:

Bilo bi kod nih još gorje izpalo, da nebude kod regimente jednoga muža

obrađena desetljeća. 
koj se je bio svojski za narod zauzeo. (Slavenski Jug, 22. X. 1848, prema Horvat 1940:92)

Da bude samo na moju, ona bi bila u obećano vreme i izišla, ali druge zapreke stadoše joj na put. (AS 1854:XXXIV-XXXV)

Narod hervatski odlučio je i vodio rat proti Magjarom, Austria i Rusia biahu naši saveznici, kojih, da ne bude izdajstva Austrie, mi nebi bili trebovali. (AS 1861c:21)

Da bude na moju, što bih ja bio učinio od tih ukaza, od listopadskoga i veljačkoga? Ja bih ih bio dao u odseke, [...] (AS 1866a:23)

To bi i bilo da nebude Sadove. (AS 1870:41)

Da nebude Napoleona, njegova Solferina, njegove Sadove, mi bi Hervati danas morali travu pasti. (AS 1879, I:128)

I da nebude Steklišah ponovismo godinu 1848. (AS 1879, II:145)

Najzad najmanja je skupina s imenskim predikatom koji je nominativ ili glagolski pridjev trpni (GPT):

Doista, da bude tom zapovedju šta boljega nameravano, ni za nju se ne bi znalo [...] (AS 1861c:3)

Nego neima dokaza ni traga ni tomu da je crkveni jezik ikada bio narodni, čisti jezik Hrvatah. Jer da bude takov, crkva bi ga bila pomogla uzdržati, on nebi bio propao. (AS 1867b:29)

S toga, da ono bude sabor, da onde budu ljudi, Austria se nebi bila usudila onu smutnju kovati. (AS 1870:43)

Bi-li on bio uznapredovao kako jest, da nebude hervatska pasmina nečistom pasminom u Arbanaskoj, u Rašii i u Serbii prevladana, u Bosni raztrovana? (AS 1876:34-35).

Razprava g. X. nebi se marila sramiti, da bude deržana u jugoslavenskoj akademii. (AS 1879, I:8)

Ah gospodine brate Rujo, da bude selo zidano i boltano, ono celo nebi bilo moglo izgoriti. (AS 1879, I:136)

Da onda nebude tako kod nas, Našinci bi bili bežeć vratove polomili. (AS 1879, I:170)

Vrijedi istaknuti da je kontekst tih rečenica uvijek prošlost, pa ne dolazi u obzir današnja parafraza s veznikom kad + kondicional (v. o tome SilićPranjković 2005:348). Primjerice rečenicu:

$\mathrm{S}$ toga, da ono bude sabor, da onde budu ljudi, Austria se nebi bila usudila onu smutnju kovati. (AS 1870:43)

mogli bismo pokušati parafrazirati ovako:

Stoga, kad bi ono bio sabor, kad bi ondje bili ljudi, [...]

ali tada bismo njezin smisao preinačili i njezina apodoza u kondicionalu II. 
jednostavno ne bi bila gramatična. Naprotiv Starčević će u kondicionalnoj rečenici s današnjim kad često upotrijebiti opet $d a+$ kondicional, o čemu više dalje (v. § IV.2). To je ovakav slučaj, gdje imamo dvaput $d a+b i(h)+$ GPR (tj. $d a+$ kondicional) i onda u nastavku $d a+b u d e m+$ GPR:

Da i nebi Beč u tom poslu imao svoje prste; da i nebi bilo treba i probitačno prostačinu obmamiti rečmi opozicie i liberalacah; da i nebude g. biškup Strosmajer težio biti i postati vodjom stranke: tko, osim njega, mogaše biti gončinom razkolnikah Slavoserbah? (AS 1870:89)

Parafrazu Starčevićeve kondicionalne protaze $d a+b u d e m+$ GPR s današnjim $k a d+b i h$ + GPR smatramo mogućom tek $\mathrm{u}$ jedincatom primjeru u kojemu je pisac priložnom oznakom (danas) posve izmiješao vremena predikacije:

Ljudi, koji se nekada proslaviše, da budu živeli danas, i kako mi živemo, za stalno nebi bili slavu stekli. (AS 1879, I:178)

Najzad ako je $\mathrm{u}$ apodozi kondicionalne rečenice s veznikom da sadašnjost (prezent), u protazi neće biti budem, nego sam, kao u ovome primjeru, gdje su u apodozama prezenti nije istina i je neistina:

Da je Posavce i Podravce glad gonila u mnogo neplodniu Ungariu, to očito nije istina; da su se oni Turčina bojali[,] to je očita povestnička neistina. (AS 1876:42)

Premda ovo zahtijeva temeljitiju analizu, reći ćemo okvirno da budućnosno značenje oblika budem $\mathrm{u}$ Starčevićevim kondicionalnim rečenicama nalazimo uz veznik ako, bilo da je budem prezent bilo da je u sklopu futura II.:

Dakle, ako budem vaš zastupnik, nemojte me suditi po onom, što bude u saboru načinjeno, nego po onom, što i o čem ja budem radio i govorio. (AS 1871b:3)

[...] ako bude tako, kamo ćemo mi do koj čas doći? (AS 1879, I:3)

[...] govorahu da ćemo najbolje učiniti ako budemo mučali. (AS 1879, I:41)

To se dobro vidi kad su oblici susljedni, kao u ovome primjeru iz Starčevićevih Ruskih odnošaja (Sušak, 1879, poglavlje "Ruski pokret”), djela koje inače nije dio našega korpusa:

Veličanstvo, da Rusia nebude imala ratah, ona nebi imala ovoliko dičnih junakah; ako nebude imala političkih borbah, ona nebude imati dosta verstnih deržavnikah. (AS, Ruski odnošaji, 1879:64)

Prva kondicionalna rečenica prošlosna je (da nebude imala $=$ današnje da nije bila imala), druga je budućnosna (ako nebude imala = današnje ako ne bude imala). Usput tu imamo futur nebude imati, o čemu više dalje (v. § IV.10). Budućnosno značenje Starčevićeva oblika budem uz veznik da do- 
lazi u finalnim (namjernim) ili konsekutivnim (posljedičnim) rečenicama, kao u ovim primjerima ( $\mathrm{u}$ drugom imamo i kondicionalnu i konsekutivno-finalnu surečenicu):

Imaju jošte i druga znamenja poslenosti, na koja sva uhoda mora točno paziti, da bude znao kod kuće istinu kazati. (AS 1845:140)

Pa makar da bude bog i nas prokleo tako da bude nas učinio jugoslavenskimi akademici, ni tada se nebi bilo pristojalo, da onaj izbor učinimo našemu zaštitniku na oči. (AS 1870:23)

U granici ima katolikah i vlahah. Da tako bude, radilo se je i radi se danas. (AS 1879, I:33)

Ostaje nam vidjeti još dvoje, prvo je kako su kondicionalne rečenice $d a+b u d e m+$ GPR opisane $\mathrm{u}$ devetnaestostoljetnim gramatikama i radovima, drugo je provjeriti koliko su one u realnu jeziku bile zastupljene. Što se prvoga tiče, Veber ih u svojoj školskoj sintaksi nije opisao (1859). ${ }^{13}$ Opisao ih je uvijek pouzdani Maretić u poglavlju o sintaksi onoga što on zove »II. složeno prošlo vrijeme«, tj. sveze budem čuvao sa značenjem prošlosti (1899:614-615). Takvu svezu, kaže Maretić, nalazimo samo u zavisnim rečenicama. Dio danih primjera ima veznik ako, no nahodimo i ove:

da me budeš za Ivana dala, sad bi ono moji svati bili (Maretić 1899:614)

daću t' za nju lipo dugovanje, štono bi(h) ti i za brata dao, da mi g' budeš živa ostavio (Maretić 1899:615)

Prvi potpuno odgovara Starčevićevu tipu s kondicionalom u apodozi. Još prije Maretića ili istodobno s njime takve je rečenice u narodnim pjesmama - omiljenu vrelu filologâ karadžićevske tradicije - primijetio i opisao August Musić u radovima o kondicionalu (1896) i rečenicama s veznikom da (1900). Kaže Musić da »dolazi kompozicija >(po)hvalio budem< [...] i u irealnim hipotetičkim rečenicama « te da tada »kompozicija >budem (po)hvalio znači radnju, koja je gotova u vrijeme, koje se fiksira perfektivnim prezentom >budem<, a vrši se prije toga vremena « (1896:159), odnosno »Mjesto kompozicije >(po)hvalio sam < dolazi za prošlost i kompozicija >(po)hvalio budem«« (1900:79). Musić je dao i više primjera, ne čudi što ćemo neke poslije naći u Maretića:

Da me budeš za Ivana dala, / Sad bi ono moji svati bili. (Musić 1896:159; 1900:79)

Da ne bude Zilije djevojke, / Nikad bi me kuća ne vidila. (Musić 1896:159; 1900:80)

Pošlji meni moga brata đordu, dat ću t’ za nju lipo dugovanje, štono bi ti i za brata dao, da mi g' budeš živa ostavio. (Musić 1900:79)

13 U njega je čitavo XXI. poglavlje posvećeno vezniku da (v. Veber 1859:133-136). 
Musićeva je ocjena ova: »Pa i danas se još kadšto upotrebljava kompozicija >dala budeš`, kao što navedeni primjeri pokazuju. Otuda se vidi, da jezik nije još posve zaboravio, da su hipotetičke rečenice sa >da< upravo eksplikativne rečenice« (1900:81). To nas vodi našemu drugom spomenutom zadatku - vidjeti realnu uporabu takvih rečenica u 19. stoljeću i što bi to značilo da se »kadšto upotrebljavaju«, kako Musić reče. Ponovimo, iz obrađenoga korpusa Starčevićevih tekstova ekscerpirali smo njih stotinu i pedesetak. Pretragom pak saborskih dnevnika iz 1860-ih (SD 1861 [1862]; 1865-1867; 1868-1871), koji obasežu neke tri tisuće stranica, uspjeli smo pronaći njih sedam, odnosno osam (!), od toga četiri u govorima Ivana Vardiana i dvije u govorima Ivana Perkovca:

Pored silnih neprijateljah mogao je narod naš propasti, da ga nebude bila čuvala njegova narav, da nebude bilo vazda muževah, koji su pirili vatru rodoljubja. (Mirko Šuhaj, SD 1861 [1862:172])

Da nebude naš milostivi kralj okružen zlosretnimi savjetnici, to bi se on bio jamačno jur sklonuo na to, da nam povrati naš podpuni ustav, [...] (Ivan Vardian, SD 1861 [1862:349])

Da budem prije došao u sabornicu, da dodje prije na mene red govoriti, nebi bio mogao preboljeti, da neizbrojim jade nam po Magjarih nanešene, [...] (Ivan Vardian, SD 1861 [1862:350])

Da budu naši pradjedovi god. 1102 složni, nebi jim bilo trebalo tudjinca Magjara birati za kralja; [...] (Ivan Vardian, SD 1861 [1862:350])

Nesloga, kleta nesloga uzrokovala je našemu narodu sve zlo, a tko znade, nebi li mi bili zadržali naš ustav, da nebude medju nami god. 1848 klete nesloge. (Ivan Vardian, SD 1861 [1862:350])

[...] neću, rekoh, zašutiti, da smo u počeli raditi na temelju neustavnom, to jest na temelju diplome od 20. listopada, jer da te nebude, mi po svoj prilici danas još nebi ovdje viećali; [...] (Ivan Perkovac, SD 1861 [1862:570])

G. zastupnik čabarski izvolio je odboru prigovoriti njeku pristranost, a to je poteklo odtuda, što on nije proučio potanje sve §§. predložene osnove; jer da to bude učinio, bio bi se uvjerio, da je broj velikašah isto tako ograničen, kao što je ograničen i broj zastupnikah crkve. (Ivan Perkovac, SD 18651867:281)

To hoće reći da je Starčevićeva (i Vardianova, i Perkovčeva) kondicionalna protaza $d a+b u d e m+$ GPR morala suvremenicima biti izrazito neobična i obilježena. Jesu li u njoj prepoznavali "osebujnost" ili možda tek narodski, ruralni govor, ili im je možda zvučala arhaično, jesu li na nju čuvenu ili pročitanu kolutali očima, to ne znamo. Ali svakako je riječ o izrazitoj odlici Starčevićeva jezika, koju hrvatska filologija dosad nije prepoznala. 
IV.2 Za razliku od prethodne (usp. § IV.1) druga vrsta Starčeviću svojstvene kondicionalne rečenice nema glagolski oblik neobična značenja, već $d a+$ kondicional u današnjemu značenju kad + kondicional. Takvih smo rečenica $u$ istraženome korpusu našli sedamdesetak. Kako od potencijalne i irealne kondicionalne rečenice s veznikom $\mathrm{kad}$ i danas očekujemo (v. npr. Silić-Pranjković 2005:348), i u protazi i u apodozi Starčević ima kondicional:

Velim něšto; jer da bi sve želio opisati, morao bi u svakom selu, pače u svakoj kući na piru biti, šta me bože oslobodi. (AS 1845:147)

[...] a da bi bili n. p. u severnoj Hèrvatskoj, imali bi se medju velike planine brojiti. (AS 1853:694)

Da bi toj Austrii sbilja stajalo do ustanovljenja toga odnošenja Hervatske naprama Ungarii, da bi Austria iskreno radila o tome ustanovljenju i pomirenju, ona si zastalno nebi bila posilila rešenje i potverdjenje [...] (AS 1863c:5)

A da bi Rusi sanjali o saveznih državah, oni bez dvojbe, nebi daveć Poljake davili same sebe. (AS 1867b:17)

Da bi Slavoserbi imali iskru uma i poštenja, oni nebi bili Slavoserbi, a da bi imali iskru otačbeničtva, oni nebi bili izdajice naroda hervatskoga. (AS 1870:32)

Metel numidski nagovarajuć Rimljane neka se žene, reče: »da bismo mogli biti bez žene, svatko bi bio bez te neprilike.« (AS 1876:13)

Da bi se radilo samo o jednomu mestu, neka bi mu bilo da radi samo za se. (AS 1879, I:146)

Da bi bilo zakona, tu bi otac morao ili venčati se sa majkom svojega deteta i dete primiti, [...] (AS 1888:15)

Da bi se to uvelo, naberzo bi nestalo komadićah na koje vlastnik često ne može leći, bez-da glavu, noge, ili ruke pruži na tudju zemlju. (AS 1890:1920)

O obliku bi za 1. SG, 1. PL i 2. PL aorista više će riječi biti dalje (v. § IV.3). Valja još imati na umu da u Starčevića - doduše rjeđe - ista konstrukcija (da + kondicional) može imati i konsekutivno (posljedično) značenje, koje je i danas prihvatljivo:

U daljini, da bi mogao do kuće mladine na tri četiri puta iz puške dobaciti. (AS 1845:144)

[...] kad bi došlo do tučnje, mi bi podbrusili pete, pa kud koje, běžali bi da nas nebi bilo moglo ni pasče dostignuti [...] (AS 1853:717)

Vrag nije tako zloban, da bi što takova izmislio, [...] (AS 1867d:123)

Uz Starčevićeve kondicionalne rečenice $\mathrm{s} d a+$ kondicional reći ćemo 
troje. Prvo, Musić ih je opisao i kazao ovako: »Po onom, što je rečeno, najsrodnije su hipotetičke rečenice sa >da bih hipotetičkim rečenicama sa ’kad bih< [...], s kojima se kadšto i izmjenjuju, samo je razlika u tom, što su hipotetičke rečenice sa >kad bih « upravo relativne, a one sa >da bih « upravo su eksplikativne«(1900:110). Dao je nekoliko primjera, u prvome usklični-

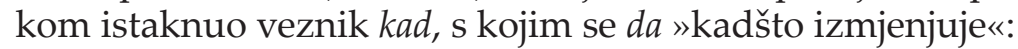

Kad bih(!) god'nu poživjela, ja bih koku podranila... Da bih drugu poživjela, ja bih patku podranila. (Musić 1900:111)

Da bi znala Budimska kraljica, da dobavi bilje i bilježje..., odmah bi se ona nabređala i rodila ka jabuku sina. (Musić 1900:111)

Da bih znala, moj jagluče zlatni, da će tebe mlad junak nositi, drukčije bih tebe popunjala... (Musić 1900:111)

Maretić također spominje rjeđi slučaj: »Kadšto pogodbeno da stoji s pogodbenijem načinom, s kojim običnije stoji pogodbeno kada« (1899:510), s ovim primjerom:

da bi se oni opomenuli onoga, iz kojega iziđoše, imali bi vrijeme, da se vrate (Maretić 1899:510)

Drugo, ne bismo li provjerili koliko je taj tip pogodbene rečenice Starčevićevim suvremenicima bio čest i živ, krenuli smo u saborskim dnevnicima (odabrali smo za početak SD 1865-1867) pretraživati svezu »da bi«. Rezultat je, kako smo mogli predvidjeti, bio taj da je veznik da izrazito čest u izričnoj službi, no relativno smo brzo pronašli i tri primjera tražene kondicionalne uporabe u triju različitih govornika, pa smo od daljnje pretrage odustali:

Da bi se bio g. predgovornik samo njekoliko trenutakah uztrpio, čuo bi bio, da predsjedničtvo poseban predlog visokoj kući podastreti kani radi preustrojstva galerije; [...] (Mirko Šuhaj, SD 1865-1867:66)

[...] ja odgovaram: da bi ja polagao junačtvo, srčanost, courage-u u riečih kao on, onda bih ja i meritorno odgovorio; nego ja u rieč nikada junačtva i srdačnosti polagao nisam, već onda, kad dojde do čina. (Avelin Ćepulić, SD 1865-1867:78)

Dvie trećine bi se jako brzo našle, da bi mi samo jedan put unutri bili, jer su ljudi vrlo čudne ćudi. (Franjo Žužel, SD 1865-1867:106)

Na temelju tog limitirana uvida možemo reći da je u Starčevićevo doba kondicionalni veznik $d a$ u značenju današnjega veznika kad relativno čest i da nije neobičan kao što bi danas bio.

Treće, ostalo nam je još pitanje rabi li i u kojem značenju Starčević veznik kad. Odgovor je kratak - da, rabi ga naizmjenično i istoznačno s veznikom $d a$, primjerice: 
[...] ja se bojim da, kad bi za uvet združenja ustanovili, da mi na Dunaju, na Dravi i na Muri s narodi Ungarie u petdesetih godinah samo jednom stada napajamo, bojim se, velim, da [...] (AS 1861c:25)

$\mathrm{S}$ toga ja kad nebi imao drugoga posla, a nebi mi se dalo spavati, volio bi buhe lovit nego-li učiti se iz njemačkoga knjižetva. (AS 1866a:24)

Kad bi na to došlo, tko bi nas narodnjake trebao, tko-li bi nas slušao? (AS 1879, I:175)

Ako se promisli napredak što bi ga i ti ljudi u gospodarstvu mogli postignuti kad nebi bili tom slaboćom obuzeti, [...] (AS 1888:5)

Kad bi se ustanovilo da kroz komasaciu može svoj posed povećati samo onaj koj [...] (AS 1890:18)

$\mathrm{K}$ tomu veznik kad može doći s prezentom, pričem se njegovo temeljno značenje neposredne anteriornosti (prethodnosti) pomiče prema značenju realne kondicionalnosti ('ako'):

[...] zadovoljih se, kad nemogu kazati celu istinu, da hotice nekažem ni malo neistine. (AS 1876:IV)

Kada čujem žensku govorit nemački, odmah znam tko je; [...] (AS 1879, I:XVII)

IV.3 Zastat ćemo načas i osvrnuti se na oblik glagola biti u kondicionalima u svim primjerima u § IV.2. Lijepo se u njima vidi da on u svim licima redovito glasi bi. To ne ističemo kao odliku Starčevićeva jezika, nego konstatiramo kao činjenicu jer vidjesmo da je tako i u drugih govornika (v. potvrde M. Šuhaja, A. Ćepulića, F. Žužela). Podsjetimo da su onodobne gramatike u pogledu oblika toga pomoćnog glagola više nego tolerantne prema praksi. Babukić za svršeni perfectum navodi doduše 1. SG běh (bih), 1. PL běsmo (bismo), 2. PL běste (biste), 3. PL běhu (biše), ali u onome što zove optativ i subjunktiv ima 1. SG ja bih ili bi, 1. PL mi bismo ili bi, 2. PL vi biste ili bi, 3. PL oni bihu ili bi (1854:272, 275), dakle gotovo se ravnopravno odnosi prema potpuno sinkretiziranoj paradigmi. Mažuranić u sadanjem pomoćnom vremenu ima paradigmu bih, bi, bi, bismo, biste, bi, ali odmah u bilješci domeće da se »u někojih stranah neproměnjeno govori u obojem broju ja-bi, ti-bi, on-bi, mi-bi, vi-bi, oni-bi« te da različiti oblici dolaze $u$ »boljem jezi$\mathrm{ku} \ll-b i h, b i$, bi, bismo, biste, biše (1859:79). Stoga je pri čitanju Starčevićevih kondicionala zapravo upadljivije i zanimljivije kad naletimo na bih ili bismo, kao u ovim primjerima, nerijetko "miješanima", malo bi malo bih, bismo, biste:

S toga, da bi ja bio deržavljanin zemlje, koja naprama prestolju neima ugovorna prava, ja bih, nad onimi rečmi ukaza plakao, [...] (AS 1866a:6)

Da bi mi, ovaj čas, zdravje dopustjalo, ja bih o iniciativi obširno govorio, 


\section{[...] (AS 1866a:10)}

A da bih ja bio Englez, da bi prava moje domovine u životu bila, ja bih se nad onimi rečmi ukaza samo smehao, ter bi rekao da je to [...] (AS 1866a:7)

Metel numidski nagovarajuć Rimljane neka se žene, reče: »da bismo mogli biti bez žene, svatko bi bio bez te neprilike.« (AS 1876:13)

Da biste barem medju se bili složni, i veran jedan drugomu. (AS 1879, I:98) Da vas nebi mi, svojim putem i načinom dizali; da nebi vi mogli slabe i zle djake naganjat i strašiti: koga biste imali slušateljem učenosti vaše? (AS 1879, I:96)

Oh da budemo god. 1861. znali ovo što danas znamo! Mi se nebi bili zaneli [...] Mi vas nebi uzaludu kermili, nego bismo bili svojski prigerlili podpun program Steklišah, [...] (AS 1879, I:99)

[...] oh tada, tada gospodo moja, mi bi imali cenu i još kakovu! Nebi se marili nuditi, nego bismo mogli dobročinitelje probirati, a oni bi se za nas jagmili, i nadtecali u plaćanju. (AS 1879, II:90)

Ponovimo, nesinkretizirani oblici kondicionalne kopule iznimka su i tako se prema njima u pristupu književnomu jeziku sjeverne Hrvatske 19. stoljeća treba odnositi. Sve što možemo reći - premda bi ovo tražilo detaljnu analizu svih primjera neovisno o kondicionalnim rečenicama - jest da će se nesinkretizirani oblici kopule (dakle bih, bismo, biste) češće pojaviti ako lična zamjenica nije iskazana, kao što daju naslutiti i sljedeći primjeri:

$\mathrm{Nu}$ zašto bismo protresivali stvari koje stoje od drugih, ne od nas? (AS 1870:12)

S toga mi bi volili da stoji Austria uz slobodnu i srećnu Hervatsku, nego da Austria propadne, bez da se Hervatska pomogne. (AS 1870:28)

Da vas nebi mi svojim putem i načinom dizali; da nebi vi mogli slabe i zle djake naganjat i strašiti: koga biste imali slušateljem učenosti vaše? A da nebiste mogli tudjim novcem papir merčiti: [...] (AS 1879, I:97)

IV.4 Kao što je u Starčevića upadljiv kondicionalni veznik da sa značenjem današnjega kad (v. § IV.2), tako u njega nahodimo i dosta primjera s temporalnim veznikom dok na mjestu na kojemu bismo danas u njegovanu jeziku očekivali također kad, upravo čim, najpreciznije rečeno - dok s neposredno anteriornim značenjem. Evo tek nekoliko odabranih primjera:

Pa itako mi kukavci hoćemo da smo junaci, mi koji bežimo dok neprijatelja ugledamo, [...] (AS 1853:695)

$\mathrm{Nu}$ Austria dok se oćutila sigurnom, zakle se proti Hervatom kako i proti Magjarom. (AS 1861c:20)

Tako, premda iz doba pyramidah neima nikakove povjesti o Egipćanih, ja dok čujem o njihovih pyramidah i drugih sgradah koje i danas stoje, bez 
obzira na pisma i povjest, zaključujem [...] (AS 1867b:8)

Sada, nečista pasmina, mogaše samo u potaji rovati, a dok bi se to opazilo, ona moradiaše na sajam, ili pod mač, ili bežati izpod dosega turske vlasti. (AS 1876:31)

[...] da mnogi Slavoserbi neznadu što rade i zato da će uz istinu i napredak pristati dok vide ove svetinje; da će, dok se osvedoče, i drugi i Slavoserbi, ostaviti izdajice i izdaju [...] (AS 1879, I:XIX)

Dok me vidiše, poznadoše da sam narodnjak. (AS 1879, I:71)

Takve je u Starčevića mnogo lakše naći negoli one u kojima dok ima simultano značenje:

Dok se zemlja tako obradjivala, ona radja u izobilju, [...] (AS 1876:12) gdje usput vidimo aorist radja umjesto imperfekta radjaše (usp. dalje § V), ili one $\mathrm{s}$ terminativnim (graničnim) značenjem, ${ }^{14} \mathrm{u}$ kojima se danas dok može zamijeniti sa sve dok:

Ja ću se, dakle, služiti slobodom govora, dok [= sve dok] mi to nebude zabranjeno. (AS 1866a:18)

Kao oznaka neposredne anteriornosti značenja zavisne surečenice u odnosu na glavnu u Tkalčevića je nedvojbeno opisan veznik čim, koji znači »da se je čin glavne izreke taki počeo, čim se je podredjene dočeo « (1859:127; 1873:181), veznik dok u njega je opisan ponajprije kao simultani i terminativni. Naprotiv u Maretića se jasno kaže da »veznik dok kadšto znači isto, što čim « (1899:504). U Starčevića veznik čim nalazimo rijetko, i to - dojam je - samo u ranijim tekstovima, a i tad se izmjenjuje sa dok, kako pokazuje drugi primjer:

Čim se ove ceremonie dogotove, idu svi skupa u kèrčmu, za da štogod založe, da tako lakše dopru kući. (AS 1845:142)

Ovaj se opis neda procieniti: iz njega se vidi, kako domaća vlada za svoj narod skèrbi, kako sloboda poštenu vladu sve to većma učvèrstjuje, kako narod bolji biva, čim mu je bolje, a dok vlada počme neljudski postupati, odmah se i narod uznemiruje, [...] (AS 1851b:662)

Što se tiče suvremenih sintaksâ, Silić-Pranjković konstatiraju anteriornu uporabu veznika dok, s primjerom Dok krenete kući, pošaljite telegram (2005:336), Katičić ju međutim nalazi »u starinskom jeziku«, primjerice Dok s ključem zakrenuše, odmah se vrata otvoriše, a da se $\mathrm{u}$ »suvremenom neutralnom stilu « u tom značenju rabi veznički izraz samo dok, primjerice Krenut ćemo samo dok kupim kartu (1986:234). Naš izvornogovornički osjećaj blizak je Katičićevu opisu, rečenice s neposredno anteriornim dok nisu 338).

14 O terminativnim temporalnim rečenicama v. npr. Silić-Pranjković (2005:337- 
nam neutralne, nego regionalno obilježene i smjestili bismo ih u niži, nenjegovan registar. ${ }^{15}$

Sad, ako se ni danas nećemo složiti oko prihvatljivosti dotičnih rečenica, što li tek možemo znati o tome jesu li one bile prihvatljive Starčevićevim suvremenicima? - Sve što možemo jest pokušati naći takve rečenice u saborskim dnevnicima (npr. SD 1865-1867). Pokušali smo i zaključili da simultano dok ('kad, u vrijeme kad') i terminativno dok ('sve dok, dok god, dotle dok') pronalazimo veoma lako i često, a da ni nakon stotina stranica ne nalazimo potvrdu za anteriorno dok ('čim, odmah pošto'). Najbliže što smo pronašli jest jedno kauzalno, uzročno dok (usp. Tkalčević 1873:181; Silić-Pranjković 2005:343), koje je blisko sa čim:

Ugarski sabor to još nije izjavio uredno, ali de facto je priznao ravnopravnost našu, dok se je upustio u dogovaranje, [...] (Ant. Stojanović, SD 18651867:554)

Na temelju toga skloni smo misliti da je Starčevićevo anteriorno dok suvremenicima 1860-ih moglo biti obilježeno, kao što je nekim govornicima danas, 150 godina kasnije.

IV.5 Kad smo već kod temporalnih veznika (usp. § IV.4), više je nego upadljiva Starčevićeva uporaba anteriornoga veznika kon što na mjestu današnjega nakon što. Pratimo ga kroz više desetljeća:

[...] ja se ovde neupustjam u prikaživanje naših pravah naprama prejasnoj obitelji Habsburgah, ja neću iztraživati da-li ova prejasna obitelj, kon što nije zabranila Austrii samovoljno gaziti onaj ugovor, što ga je Habsburg Ferdinand I. s našom kraljevinom sklopio, [...] (AS 1861c:6)

Napoleon I., kon što mu narod poveri svoju slavu i sreću znajući što je iniciativa, u svemu je lakše popustjao nego-li u njoj. (AS 1866a:8)

Kasnije kon što se ovi narodi omedjašiše svojimi narodnostmi, buduć nenadodjoše nikakovi novi Slavjani, očita je stvar da to novo slavjanstvo ima samo zemljopisno znamenovanje. (AS 1867b:8)

Kon što se onih narodah, za neobičnie stvari i višje pojme uhvatila obsežnia hervatština, one pervobitne reči ostadoše u životu dotičnih pučanstvah, [...] (AS 1871a:1)

Sudi bo se za nepravično, nagoniti ljude da opet vrat skuče poda jaram sužanjstva, i to proti obećanjem, kon što su za osloboditi se turskoga sužanjstva, javnom verom $\mathrm{k}$ nami došli. (AS 1876:48)

Niste-li svi složno potegnuli u rajhsrat, i to kon što ste se dali od Magjara osedlat, zauzdat i zajahat? (AS 1879, I:100)

15 Nitko to, nadamo se, neće pogrešno shvatiti. Jednostavno smo iskazali svoj izvornogovornički osjećaj. Ne smatramo ga ni manje ni više relevantnim od osjećaja drugih govornika i osjećaja pisaca gramatika. 
U stanju kakovo je kod nas, ta zadruga nemože se ni pol godine kruhom hraniti, ni kroz polovicu zime prekermiti nekolike glave, kon što je podmirila različne štibre i globe, i začepila druge najprečje potrebe. (AS 1888:1011)

Kadšto se taj veznik pojavi uz prijedlog nakon ili veznik nakon što, primjerice:

[...] pa nakon što bi bili pravilno razpravljeni i pretrešeni, kon što bi bili došli na dnevni red, [...] (AS 1866a:23)

Neima sablazni nad onu, da se Rimljanin nakon sedam vekovah slobode i slave, kon što zemlju svlada, dao na učenje govorničtva. (AS 1876:14)

Ta neobična svezica kon što - sama po sebi izvanredno zanimljiva - otkrit će nam nešto čemu se nismo nadali. Razložit ćemo u tri dvokoraka. Prvo, ni Babukić (1854), ni Veber (1859), ni Maretić (1899), ni ARj ne bilježe veznik kon što. Dodajmo odmah drugi korak prvog dvokoraka: ne bilježe ni veznik nakon što. Drugo, računalno smo pretražili šest knjiga saborskih dnevnika (SD 1861 [1862]; 1865-1867; 1868-1871; 1872-1875; 1878-1881 [1903]; 1884-1887), što je šest-sedam tisuća stranica teksta. Nismo pronašli nijednu potvrdu veznika kon što osim onih koje je izgovorio Ante Starčević! Kao da to nije dovoljno, sad slijedi drugi, pomalo iznenađujući korak drugog dvokoraka: $u$ tih šest-sedam tisuća stranica pronašli smo jedva petnaest potvrda za nakon što, od toga većinu u SD (1878-1881), drugim riječima, sve do 1878. veznik nakon što kuriozitet je, a Starčevićevo kon što kuriozitet je kurioziteta. Budući da smo tako otkrili ono što nismo tražili, dat ćemo dvije najstarije potvrde i tri Starčevićeve, naime od petnaestak potvrda veznika nakon što tri su njegove:

Predlog ovaj bi, nakon što bi ga više članovah kriepko podupiralo bilo, primljen. (Zapisnik, SD 1861 [1862:540])

Nakon što se je usljed previšnjega kraljevskoga reskripta od 7. studenoga 1868. i zakonskoga članka XXX. 1868. §. 66. 1. sazvana regnikolarna deputacija konstituirala, [...] (Zapisnik, prijevod s njemačkoga, SD 1868-1871:831) [...] da prije onoga rata kraljevina Hrvatska nastavi rat proti Turčinu, nakon što kraljevina Ungarija bijaše s Turčinom mir sklopila; [...] (Ante Starčević, SD 1878-1881:85)

Nakon što je razpravljanje dovršeno, mene u sjednicah nije trebalo, zato nepribivah onoj u kojoj su zapisnik i izvešće podpisani. (Ante Starčević, SD 1878-1881:1486)

[...] ter da nemože u danih okolnostih odgovarati za spise nakon što odu iz njezinih ruku. (Ante Starčević, SD 1878-1881:1487)

Treće, kad sažmemo, što tu dakle imamo. Imamo to da se anteriorni veznik nakon što, koliko na temelju nemala istraženoga korpusa možemo za- 
ključiti, u hrvatskome - očito pod utjecajem njemačkoga nachdem jer vidimo u primjerima da se pojavljuje u prijevodima - počeo širiti negdje 1870-ih. Maretić će ga u Savjetniku iz 1924. još uvijek smatrati nevaljalim:

nakon što, nachdem, je pogreška, na pr. nakon što nam je to javljeno, odosmo na put; bolje: pošto. (Maretić 1924: s. v. nakon što)

U zadnjem koraku imamo to da je Starčevićevo kon što bilo i ostalo hapaks, do te mjere da prema tom vezniku možemo prepoznati da je riječ o Starčevićevu tekstu. Ako drugi suvremenici nisu rabili ni nakon što, teško je znati je li im Starčevićevo kon što uopće išta značilo i jesu li ga možda zbunjeno identificirali s komparativnim (usporednim) kao što, tj. kaono što, kono što.

IV.6 Što upravo rekosmo o forenzičkome potencijalu Starčevićeva veznika kon što (usp. § IV.5), sve do 1880-ih u sjevernoj Hrvatskoj vrijedi i za Starčevićevu prijedložnu skupinu u supor (+ DAT) značenja 'usuprot, nasuprot'. U Starčevića ju nalazimo već od 1860-ih:

Kada, dakle vičete proti ovoj nevolji Hervatske, kada velite da ištete leka proti njoj, pak se u supor prošlosti i sadašnjosti itako još zauzimljete za Austriu, vi neradite drugo nego [...] (AS 1866a: 15)

[...] hotice, u supor opomenam razumnikah [...] (AS 1867b:38)

U supor našoj prikladnosti, pravo govoreć ludoj milosti, Slavoserbi nebiahu zadovoljni. (AS 1870:25)

U supor neopisivoj meržnji koju imadoše na papu i na njegove verne, sleditelji iztočne cerkve itako priznavaše njegovu najvišju vlast, [...] (AS 1876:98)

U supor svemu tomu, poznane našince nikako nemogosmo nametnuti. (AS 1879, I:3)

U supor svemu dokaživanju, celo prosto pučanstvo smatra nas [...] (AS 1879, I:55)

Itako, u supor naprezanju, on nemogaše preko četiri pregnati. (AS 1879, I:161)

U tisućama stranica saborskih dnevnika (SD 1861 [1862]; 1865-1867; 1868-1871; 1872-1875; 1878-1881 [1903]; 1884-1887) ta je prijedložna skupina dva i pol desetljeća lakmus za Starčevićev govor, sve dok ju 21. XI. 1885. ne upotrijebe Josip Zorić i pravaš Grga Tuškan:

Stavljaju se usupor ove zak. osnove, koje ovdje stoje na stolu vis. kuće. (Josip Zorić, SD 1884-1887:1013)

[...] ako ja znadem, da ovaj zakon zabranjuje zatvor narodnoga zastupnika, pitam onda vis. vlada, što ću držati ja do toga zakona, do tih sudova, kada ja vidim, da usupor svemu tomu sudovi zatvaraju naše drugove, da sudovi usupor svemu tomu krše i gaze zakon? (Grga Tuškan, SD 1884-1887:1017) 
ARj (s. v. supor) kaže da je to 'opreka, protivnost' te daje četiri potvrde, jedna je iz Like, druga je upravo u supor u ovome radu već spomenutoga Mihovila Pavlinovića (usp. § III):

Dva načela, koja su u supor jedno drugome. (Mihovil Pavlinović, Različiti spisi, 1875, prema ARj)

Ponukalo nas je to da pogledamo ima li još što u Pavlinovića i nađosmo primjerice ovo:

A da neki vas vole uz ime pravoslavno nadjenuti i srbsko, to vam neće nitko braniti, kad narodno-državnomu imenu hrvatskomu ne budete podmetali, kô tobož u supor, srbsko narodnovjersko ime. (MP 1876:46)

Tko je od koga posuđivao, ne znamo. Kako god, očito je riječ o izrazitoj odlici Starčevićeva (i Pavlinovićeva) jezika.

IV.7 Skupina $u$ supor (usp. § IV.6) dalje nas vodi vezniku ali, koji u Starčevića može biti i disjunktivan (rastavan) i adverzativan (suprotan), barem u 1850-ima i 1860-ima. Čini se da ga poslije 1860-ih u disjunktivnoj službi nadomješta ili (kod udvojenoga ili ... ili to može biti i očekivano budi ... budi). Dva značenja veznika ali najbolje do izražaja dolaze u rečenicama u kojima su oba:

Mi nikad nismo ništa imali s Vrazom, van što smo ga sažaljivali u bolesti njegovoj, i što danas za njime žalimo; ali [2] itako, nimalo se nebojimo, da ćemo istinu uvriediti, ali [1] da će nas ko pristranostju ukoriti, ako rečemo, [...] (AS 1851a:653)

Ja znam, da cerkva nije bila vazda razdieljena polag političkoga uredjenja deržavah, ali [2] je cerkva hervatska služila se od početka i služi se i danas svojim hervatskim jezikom. (AS 1852b:602)

Ali [2], možda misli tko, da je odnošenje naše domovine naprama Ungarii neizvestno, da je sumnjivo, Ungaria bo, ali [1] bolje rekuć Magjari vele, da je Hervatska Ungarii ali [1] Magjarom bilo kako podložna, a Hervati neće da to priznadu. (AS 1861c:9)

Brojkom (1) označili smo disjunktivnu službu (današnji veznik ili), brojkom (2) adverzativnu (današnji veznik ali). Disjunktivno ali u Starčevića je 1850-ih i 1860-ih veoma često:

Jer, ali će pisati: mošći, plašć, ali moći, plać, ali će doći na ovo, na što sam i ja došao [...] (AS 1850 [1852:230])

[...] jer bi takovim govorilo samo nekoliko čeljadi, ali, najviše, nekoliko hiljadah dušah. (AS 1851c:694)

Uvrede ali svadju neka niko meni nepripisuje, [...] (AS 1852b:602)

[...] - bilo ovo ali ono, Austria neima pravo mešati se $u$ te naše poslove. (AS 1861c:5) 
[...] nego da on može onaj ugovor, kao što se s njegovom koristju slaže, preinačiti ali posve ukinuti. (AS 1861c:18)

Kako rekosmo, dojam je da ga u 1870-ima nadomješta disjunktivno ili, kao u pozdravu kojim svršava mnogo pismo Magjarolacah (AS 1879) - il u vatru il u vodu. Evo još nekoliko primjera:

Sada, nečista pasmina, mogaše samo u potaji rovati, a dok bi se to opazilo, ona moradiaše na sajam, ili pod mač, ili bežati izpod dosega turske vlasti. (AS 1876:31)

[...] jedan se opije da o sebi nezna je-li mužkarac ili je ženska, je-li dan ili je noć. (AS 1879, I:70)

Neverujem da će se ikoj pravi hervatski mali ili srednji posednik uteći $\mathrm{k}$ tomu vašemu zakonu [...] (AS 1890:20)

Premda je disjunktivno ali i danas prisutno kao regionalizam s mogućom jakom stilogenom službom, toliko da se spominje i u suvremenoj sintaksi (v. Katičić 1986:165), i premda ARj (s. v. ali) upravo disjunktivnu službu navodi kao prvu, pa ju očekivano opisuje i Maretić (1899:496), premda i KRj (s. v. ali) ima disjunktivnu službu, doduše na drugome mjestu, ali s više potvrda (što bi bio metodološki lapsus), gramatike Starčevićeva doba nemaju disjunktivno ali, imaju samo adverzativno, tako Babukić (1854:406-407) i Veber (1859:122-123; 1873:177-178). Pregledali smo stoga nasumce par stotina stranica saborskoga dnevnika (SD 1861 [1862]) te utvrdili da se disjunktivno ali zapravo ne može pronaći, dočim za adverzativno ali potvrda ima na stotine. I tako pomalo neočekivano dođosmo do toga da je Starčevićevo disjunktivno ali suvremenicima moralo biti isto što je nama danas - izrazito stilogen regionalizam koji povezujemo s posebnim vrstama pučkih poslovičnih ili frazeologiziranih izričaja (npr. šutit kano kamen ali drvo iz Matijaša grabancijaša dijaka Tituša Brezovačkog).

IV.8 Nadovežemo li se na adverzativno ali iz prethodnog odjeljka (usp. § IV.7), uočimo još da adverzativno $n u$ u Starčevića nahodimo redovito i dosljedno od 1840-ih do 1890-ih:

U ostalom znam, da nisam dosta učinio, nu gledati ću naskoro nadoknaditi. (AS 1845:147)

Nu Austria dok se oćutila sigurnom, zakle se proti Hervatom kako i proti Magjarom. (AS 1861c:20)

Gospodo, ja najradje mučim, nu kad govorim, ja govorim kako mislim i ćutim. (AS 1861c:34-35)

Iz ukaza 8. studena 1861. moralo bi se pretresti više točakah, nu ja ću samo naseći onu seč kojom se kaže da su otci naši [...] (AS 1866a:10)

Moguće da bi i Cigani što takova učinili, nu nije moguće, da se oni nebi stidili to ikomu kazati. (AS 1870:4) 
[...] govoraše, da bi volio biti austrijski desetnik, nego li ustavan kralj, nu onaj nesretnik danas se sakriva tudjim redarstvenikom. (AS 1878:4)

Neznam kako je kod vas; nu ja smatram zadrugu onakovom kokova je bila kroz vekove, i kakova po svojoj naravi mora biti. (AS 1888:23)

Adverzativno nu imaju Babukić, koji ima i no (1854:406), i Tkalčević, koji nema no (1859:122; 1873:178), dok Maretić nema $n u$, ima samo no, koji da je »veoma običan veznik « $(1899: 493,495)$. Nekoliko sekundi računalne pretrage saborskih dnevnika (npr. SD 1861 [1862]; 1878-1881) dovoljno je da se utvrdi da je $n u$ od 1860-ih do 1880-ih običan i čest adverzativni veznik. Status i čestotnost veznika no u drugoj polovici 19. stoljeća prepustit ćemo drugim istraživačima.

IV.9 Među morfološkim odlikama Starčevićeva jezika tu i tamo zapela nam je za oko ponekadnja sklonidba brojeva od pet naviše. Nije nepoznato da preporuka o sklonidbi brojeva od pet naviše u gramatikama druge polovice 19. stoljeća polako, ali sigurno labavi. Babukić ih ne sklanja, tj. daje slovensku paradigmu i kaže da se u ilirskom književnom štokavskom ne sklanjaju (1854:220), Mažuranić u bilješci zdvaja nad zaboravom slavenske deklinacije glavnih brojeva i gubitkom padeža (1859:58), Tkalčević konstatira da se $» u$ novijem jeziku, osobito štokavskome, glavni brojnici, počam od pet, dèrže svuda za nesklonive samostavnike« (1873:53), Maretić jednostavno kaže da se »brojevi 5-90 ne sklanjaju nikako« (1899:219). Nećemo se baviti kontrastivnom analizom s drugim suvremenicima, samo ćemo kazati što nahodimo u Starčevića, pričem imamo na umu metodološke poteškoće - brojevi su često pisani brojkom pa relativno neupotrebljivi za jezičnu analizu, a akuzativni oblici ionako su jednaki nominativu. Sve u sve$\mathrm{mu}$, nailazimo u Starčevića tu i tamo na deklinaciju brojeva od pet naviše, evo potvrda za lokativ i genitiv iz 1860-ih i 1870-ih:

[...] ja se bojim da, kad bi za uvet združenja ustanovili, da mi na Dunaju, na

Dravi i na Muri s narodi Ungarie u petdesetih godinah samo jednom stada napajamo, bojim se, velim, da [...] (AS 1861c:25)

Ja sudih ovako: neima dokaza ni razloga verovati, da bi ijedan taj čovek od desetih jestvinah na dan, kroz godinu [...] (AS 1870:15)

Hervatskoga zastupstva iz sedmih županiah sastade se ne na temelju obćenita glasovanja, [...] (AS 1878:14)

Tko će doživeti deset godinah? U desetih godinah može čovek toliko putah umreti koliko je hipah. (AS 1879, I:134)

Da ne bi bilo pogibeljno od Austrie i Magjarah, ja bi bio već davno dokazao da moje pleme potiče od Buge, mladje sestre onih petih Hervatah koji su desno-dunajsku Hervatsku osvojili. (AS 1879, I:138) 
No još je lakše pronaći one u kojima se ti brojevi ne sklanjaju, primjerice:

[...] da imadu barem petnaestero dietce medju kojimi je najstarije od šest godinah; [...] (AS 1867d:123)

[...] nad njom bdiaše oko dvadeset posebnih bogovah; [...] (AS 1876:11)

Neima sablazni nad onu, da se Rimljanin nakon sedam vekovah slobode i slave, kon što zemlju svlada, dao na učenje govorničtva. (AS 1876:14)

Prie kakovih trideset godinah nije ni kod nas bilo tih zločinacah ni neprilikah; [...] (AS 1879, II:21)

Onda opet razbistrit zašto je onako ovo tretje onako, i tako dalje do dvanaest putah. (AS 1879, II:112)

IV.10 Kao jednu od morfoloških odlika Starčevićeva jezika Jurišić (1943:552) i Bratulić (1995:483) spominju futur budem + infinitiv (dalje INF), primjerice budu slediti, nebude odkaživati. Na temelju svojih uvida možemo o tome kazati sljedeće. Prvo, doista, u istraženome korpusu pronašli smo pedesetak takvih oblika. Značenjske posebnosti nismo im uspjeli domisliti. Što se sintaktičkih tiče, zasad primjećujemo da se taj futur ne mora naći u konjunktivnome položaju, privezan za neki veznik ili glagolski oblik, premda često dolazi uz glagole govorenja i mišljenja:

Gospodo, Austria, o kojoj ja ovde govorim, ona je herpa bečkih licomeracah i ulagah, [...] koji budu, ako stvari drugačie neokrenu, učiniti da kralj naš poveća broj onih žertvah [...] (AS 1861c:5)

[...] ali prestalo je i ono tlačenje, pa bude i ovoga nestati. To i ja verujem, nu ujedno kažem, da niti je pervašnje tlačenje dokinjeno, niti se bude ovo sadašnje dokončati. (AS 1861c:28)

[...] ako se s Ungariom realno danas sdružimo, sutra se budemo s narodi Ungarie klati, prekosutra budemo skupa s onimi narodi jaukati pod štapom Austrie [...] (AS 1861c:37)

Gospodo, možda bude doći vreme, gde ćemo čuti poziv u tu sverhu. (AS 1866a:21)

Jer kad nisu hitropisci, nije moguće da budu sav govor uhvatiti. (AS 1870:51)

Najviše železa ode na verige i strah je da bude nestati lemešah. (AS 1876:16)

Misliš-li da pišuć o tom, i pravopisom kojim se nitko nesluži, budemo dobiti čitateljah, i primamiti Slavoserbah, za-da se uče i poprave? (AS 1879:V)

Kažite što znate, ni kod kuće nebude drugo naći. (AS 1879:XX)

Čestje se budemo vidjevati. (AS 1879, II:85)

Stari Stekliš odgovori, da ovaj put nebude ništa dati ni bog ni sreća junačka. I nije slagao. (AS 1879, II:142) 
Oblici s futurom budem + INF u Starčevića su zapravo iznimka, kap u moru futurâ ću + INF. Koliko je futur budem + INF rijedak, pokazuju i primjeri u kojima dolazi uz futur ću + INF:

[...] vi koji puku kažete, da budu prestati štibre a nastati jevtinoća u sve$\mathrm{mu}$, vi, gospodo, koji tako radite, što ćete učiniti i kako ćete se pred narod pokazati kada tko dojde i kaže istinu [...] (AS 1861c:34)

Ako dakle budu slediti naputak same svoje sebičnosti, sam onaj ostan, kako će se ti ljudi u pogledu Austrie ponašati? (AS 1870:15)

Njihovi zvonari budu naš spis pod tudjim imenom deržat $\mathbf{i}$ čitat marljivie nego itko drugi, i jer neimaju razuma, oni će ga svojim pastirom dostavljat i od njih naputke pitat, a zabraniti će ga kerdu, ter svi složno budu mučat o njemu, i radit da on nedojde u veliku javnost, i da propadne. (AS 1879:IX)

odnosno s obama ostalim futurima, ću + INF i budem + GPR:

Austria će, ako ju drugi budu deržali, kako i dosada, gaziti naša prava, terti naš narod. Tako budemo i odsada, i proti našim pravom, i bez našega privolenja, od Austrie imati sve ono, čemu ona sada ište naše posvetjenje. (AS 1870:12)

Drugo, stanje u gramatikama. ${ }^{16}$ Š. Starčević ima ga, ali samo u konjunktivu (v. 1812: §§ 51-52), što u potvrdama A. Starčevića nije nužno slučaj. Š. Starčević u »kazajućem « načinu (indikativu) za »došasto« vrijeme ima ove oblike: ja ću biti, imati ću, orati ću, ljubiti ću, a u »vezajućem « načinu (konjunktivu) za »buduće « vrijeme ove: kada budem (sic!, ne kada budem biti), kada budem imati, kada budem orati, kada budem ljubiti (1812:51-61). Futur budem + INF ima i Appendini, također u konjunktivu, ali dubletno, usp. futur indikativa ja imati ću, imat ću, ja orati ću, orat ću, ja učiti ću, ja ću učiti te futur konjunktiva kada ja budem imati ili kad budem imao, kad ja budem orati ili kada uzbudem orao, kad ja budem učiti ili kada budem učio (1808:83-98). Još u 18. stoljeću Della Bella u konjunktivu također ima dubletno kada budem imati ili kad budem imao, kad budem orati ili kada budem orao, kad budem učiti ili kad budem učio (1728 [2006: §§ X-XII]). U drugoj polovici 19. stoljeća futur budem + INF nemaju Babukić (1854), Mažuranić (1859), Veber (1873), ima ga Budmani kao futur konjunktiva, usp. kad uzljubim i kad budem ljubiti, kad uspišem i kad budem pisati (1867:105), a Maretić ga spominje kao sve$\mathrm{zu}$ »sasma neobičnu u književnom jeziku«, koja da »se nalazi u narodnom jeziku južnijeh krajeva« (1899:287), sa sljedećim primjerom:

kad budemo sad na sretni put krenuti i onoj prijateljskoj kući doći, da pazi svaki svoj red, svoju čast, svoju dužnost i obraz (Maretić 1899:287)

Primjer je inače iz Karadžićeva Kovčežića (1849:58). Takve sveze, rekni-

16 U kratku pregledu koji slijedi oblike iz starih gramatika davat ćemo preslovljene suvremenom latinicom. 
mo usput, dale su arhaične sraslice poput dadbudem, htjedbudem, mogbudem, smjedbudem, znadbudem i sl. ${ }^{17}$

Treće, kontrastivno, rekli bismo da je futur budem + INF suvremenicima zacijelo bio veoma neobična Starčevićeva odlika. U saborskim dnevnicima iz 1860-ih (SD 1861 [1862]; 1865-1867; 1868-1871), što je nekih tri tisuće stranica teksta, uspjeli smo pronaći tek tuce takvih oblika drugih govornika, od čega je trećinu - gle čuda - izgovorio Starčevićev stari drug Eugen Kvaternik. Evo nekoliko primjera:

Dok nebudemo odlučiti da li smo da li smo još pod absolutnom vladom ili ne, prije nećemo imati nikakvog uspjeha; [...] (Koloman Bedeković, SD 1861 [1862:117])

Kazano je dalje, da ćedu Magjari, ako mi s njima sdružiti se budemo, ugovore za nas sklopiti, i nekako raditi o nama bez nas, [...] (Gustav Knežević, SD 1861 [1862:249])

Ali mi moramo onom cilju težiti, da naši Slavjani nebudu prosti brodari, to jest sluge tudjeg brodarstva, nego, da se i naše brodrastvo [sic!] promicati počne; za da napose tako umnog i djelotvornog naroda vlastitu korist uplode i da se slavjanski barjak u svima kutima svieta vijati bude. (Vinko Vranicany, SD 1861 [1862:304])

Ako pako visoka ova kuća bude prispodobiti izjavu g. Price takovu kakova jest, sa kralj. visokim odpisom, [...] (Eugen Kvaternik, SD 1861 [1862:560])

Ali račune kakve davati nemoram, kako to zahtjeva g. Stojanović, i ja ih od svoje strane nebudem polagati. (Miroslav Kraljević, SD 1868-1871:768)

IV.11 Kad smo već kod futura ću + INF, a vidljivo je već u primjerima u prethodnom odjeljku (v. § IV.10), recimo da neke posebne pravilnosti u vladanju infinitivnoga $i$ nema. Ako je ću enklitika, infinitiv će uglavnom imati $i$, ali ne dosljedno. $S$ druge strane infinitiv počesto neće imati $i$ ondje gdje bismo ga možda očekivali. Dojam je da se po tome Starčević od svojih suvremenika nije odveć razlikovao. Evo tek nekoliko primjera nedosljednosti unutar iste rečenice:

[...] narod hervatski neće terpiti, da ta sužanjska pasmina oskvernjuje svetu zemlju Hervatah; narod hervatski dade novo pokolenje koje će obnovit i učverstit njegovu sreću, slavu i veličinu; narod hervatski kroz i uz svoje sinove i prijatelje okrepit će se na suncu, [...] (AS 1870:58)

[...] da je isto, učiti Slavoserba ili vola; da će Slavoserb, kako hoćete, sve priznat, sve dopustit, i svakako govoriti, nu itako po svoju radit; [...] (AS 1879, I:XIX-XX)

17 Usp. također Maretićev opis futura II. u zavisnim rečenicama (1899:629-630). 
IV.12 Leksikom se u ovome radu ne bavimo, ali jedan Starčevićev rječogradni postupak ne možemo zaobići. Koliko znamo, Starčević se prvi u nas služio stapanjem i tako začeo važnu tradiciju unutar hrvatske satire koja traje do danas (v. Marković 2016). Ojađenost politikom i nemoć da se unutar institucija išta pomakne gurnula je Starčevića u satiru, najizraženiju u Pismima Magjarolacah, koja su krenula dijalogom "Oklad" u Zvekanu (AS 1867d), nastavljena - često anonimno - u pravaškim listovima, posebice sušačkoj Slobodi, najzad objavljena kao zasebna autorska knjiga u dvama dijelovima s 28 pisama (AS 1879). U njima se pisac na tragu već spominjane blekavštine (v. npr. AS 1852b:603, usp. § II.3) znao poigrati riječima pa primjerice od silogizama i proletera stvoriti sigulizme (AS 1879, I:56) i petrolere (AS 1879, I:69), koje riječi ne smatramo stopljenicama, ali najavljuju tendenciju. Starčevićeva protostopljenica još je starija i nalazimo ju u napisu "Starost" u Obćem zagrebačkom koledaru za god. 1850. Starčevićevo autorstvo nije nedvojbeno, pa oko njega ne možemo biti decidirani. ${ }^{18}$ Stopljenica bi ako je stopljenica, dakle ako je svjesna i ako ju umijemo protumačiti - bila riječ novinkar (novinar $\times$ hodkar 'doušnik, potrkivalo'): ${ }^{19}$

Starcu sve je sumnljivo, on se služi orudjem i uhodami; on miluje laskanje i zato rada vidja oko sebe svitu bezposlicah i favoritah, dopada mu se mehkoputnost, udobnost, pletke, pričice: njemu se utiču metrese, jezuiti i novinkari. I vlastita ga deca nemogu ljubiti, već dàrhću pred njegovom senom. ("Starost", Obći zagrebački koledar za god. 1850, prema Horvat 1940:109)

Udarna i naslovna Starčevićeva stopljenica Magjarolac (Magjar $\times$ Tirolac) prvi se put javlja na naslovnici Zvekana 1. IX. 1867. s ovakvim tumačenjem u fusnoti:

Skraćeno od Magjar i Tirolac. Jer stranka narodno liberalna izjavi u Pešti da smo Magjarska zemlja a kašnje u Beču da smo Tirolci. (Zvekan, god. I, br. 16 /1. IX. 1867/, str. 85)

Starčević je za narodnjake inače rabio riječ Slavoserbi, ali prigrlio je Magjarolce i rabi ih u Zvekanu već 1. XI. 1867. u dijalogu "Stekliš i prostodušnik":

18 Drechsler veli »Oba su članka od istoga pisca, pa i ako on nije nikako naznačen, nema nikakve sumnje, da potječu od Starčevića« (1912:367), Horvat u Starčevićevo autorstvo ne sumnja (1940:107), Ladan je neodređen (1971:68), a Jurišić kaže ovako: »Josip Horvat u svojoj knjizi (Ante Starčević, str. 107) misli, da su u zabavnom dielu kalendara pretežno prilozi iz Starčevićeva pera. Ja se o tome nisam mogao uvjeriti« (1943:542). Spomenuti Horvat dapače piše da su napisi »Djetinjstvo, muževnost, mladost, starost « i »Starost « - »prva dva eseja u modernoj hrvatskoj književnosti, pisana na način, moguće čak nadahnuta Montaigneovim djelom «(1940:107).

19 Takvoj raščlambi Ladan pridružuje i imenicu papkar (1971:68); značenje hodkara 'doušnik, potrkivalo, tajni agent' preuzimamo od Ladana (1971), ARj i KRj ne bilježe tu riječ. 
Ta je istina da vi Stekliši griešite proti Hrvatom i Hrvatskoj, kada Slavjane, Magjarolce, i kako se sve zove taj nečisti nakot, zovete blagom, marvom, ili kojim drugim dosada običajnim imenom. (AS 1867a:120)

Poslije ju je rabio redovito te stavio u naslov knjige, s ovim objašnjenjem u proslovu "Na štioca":

Nije druga, ništa nekoristi, van dajmo "pisma Slavoserbah.« Ali ne, jer je "Zvekan" preporučio ime »Magjarolac«, kerstimo ih barem za sada, "pisma Magjarolacah.« (AS 1879:XXI)

U pismima onda nahodimo još stopljenice samosralac (samostalac $\times$ liberalac $\times$ srati, AS 1879, I:105), ${ }^{20}$ monantonia (monotonija $\times$ onanija, AS 1879 , II:57) i kloakofonia (kloaka $\times$ kakofonija, AS 1879, II:57-58). Ponovimo, koliko danas znamo, to su prve svjesne autorske hrvatske stopljenice, začetak onoga što će se dalje nasljedovati u pravaškoj satiri (A. Kovačić, A. G. Matoš) i razviti do današnjih neslućenih razmjera. ${ }^{21}$

V. Ostaje nam još nabrojiti nekoliko uočenih odlika Starčevićeva jezika kojima se u ovome radu nismo bavili, a zaslužuju biti spomenute, jednom i zasebno obrađene, eda bi se nakraju vidjelo jesu li Starčevićeve posebnosti ili se uklapaju u opću sliku neutralnoga hrvatskoga književnog jezika druge polovice 19. stoljeća.

Prvo, izrazito česti veznici za da, bez da, van (također van da, van ako, van što i sl. te njihov odnos prema osim, osim što i sl.).

Drugo, izrazita čestotnost konstrukcije $z a+$ INF, koju je primijetio i Jurišić (1943:552), naime nije ju mogao ne primijetiti, kojoj bi valjalo pronaći mjesto onkraj savjetničkoga zgražanja nad njom.

Treće, članska služba demonstrativa isti, riječi koja se s neprozirnim značenjem u Starčevića stalno pojavljuje kao dio imenske skupine.

Četvrto, izostanak ili rijetkost povratno-posvojne zamjenice svoj za 1 . i 2. lice.

Peto, besprijedložni partitivni genitiv imenica (usp. Jurišić 1943:552553) i ličnih zamjenica (npr. jedan njih) i s time povezan posvojni pridjev od lične zamjenice (npr. njihov, njegov).

Šesto, perfekt bez kopule gdje ga ne bismo očekivali, osobito u temporalnim rečenicama, primjerice:

Kad Poljaci oslobodili Beč i carstvo, car Leopold učini vojvodu bavarskoga svojim zetom, [...] (AS 1876:53)

20 Kao igru riječima, upravo kao »neobičnu Starčevićevu tvorevinu « primijetio ju je još Škreb (1949:129).

21 O kronologiji stapanja u hrvatskome v. Marković (2016). 
Dok Hervati i narodi Ungarie poznali begunce, opazilo se da u ovih neima kerstjanstva. (AS 1876:99)

Da nebi bilo Steklišah, ni danas nitko nebi znao za tu našu praktičnost, prem ju javno učinismo, prem ju na desetke tisućah dušah čitalo. (AS 1879, II:35)

Kad Rauh nedao službe ni plaće, kad Magjarom nemogli naškoditi: mi udarismo na Rauha [...] (AS 1879, II:146)

Kad došlo vreme da se obnovi perva petina zakonotvorna tela, Napoleon [...] (AS 1889:52)

Sedmo, proboji tzv. novih pluralnih padežnih oblika (zapravo starih dualnih) $\mathrm{u}$ dativu, lokativu i instrumentalu, osobito $\mathrm{u}$ ličnih zamjenica (npr. nama, vama, njima umj. nami, vami, njimi).

Osmo, aorist umjesto imperfekta ( $\mathrm{tj}$. imperfektno značenje iskazano aoristnim oblikom), npr. braniše umj. braniahu (AS 1870:1), bojaše umj. bojahu (AS 1870:21), radja umj. radjaše (AS 1876:12), zahteva umj. zahtevaše (AS 1878:5), radiše umj. radiahu (AS 1889: 24, 39), što je već primijećeno (Jurišić 1943:553; Bratulić 1995:484).

Deveto, redovito čuvanje komparativnoga i instrumentalnoga $j$ iza postalveolara i palatala (npr. težji, pomoćju), ili bolje, u kojim se slučajevima ono u tim položajima gubi.

Najzad, kako u cjelini Starčevićeva jezika stvari stoje s vjerojatno jednom od najdužih, korijenima najbogatijih složenica ikad zapisanih u hrvatskome jeziku:

Dakle čekajmo dok jugoslavenska akademia ustanovi formulu. Medjutim, za potrebu, moglo bi se govoriti n. p. Gerko-Skipetaro-Bulgaro-TalianoŠvabo-Magjaro-Rumunjo-Serbo-Pemče-Muhamedo-Lutero-Židovo-Šokačko-Kalvino-Bunjevačko-Hervat. Tako, ili povratno, ili promenjeno. (AS 1879, I:198)

VI. Nadovezujući se na $\S$ V. te na prethodne usputne napomene o Starčevićevu izgovoru slogotvornoga [r] i pluralnih sufikasa (usp. § III), možemo još natuknuti zasebnu i zahtjevnu temu - realan Starčevićev izgovor. Ako je ona preambiciozna, mnogo bi već značilo usporediti Starčevićeve objave vlastitih govora i brzopisne saborske transkripte, koliko god i jedni i drugi vjerni bili. Tek za pokus uzeli smo Starčevićev saborski govor 27. I. 1866. kako je objavljen u zasebnoj knjižici (AS 1866a) i kako je objavljen u saborskome dnevniku (AS 1866b [1867]). Pritom valja imati na umu da su u knjižici dane didaskalije (u zagradama, npr. »Smeh« ili »Živio«) i upadice predsjedavajućega koje nalazimo u saborskome dnevniku, što jasno daje do znanja da je tekst u knjižici zapravo prenesen iz dnevnika. Ako za- 
nemarimo nevažne ortografske detalje poput interpunkcije, velikog i malog slova, pisanja intervokalnoga $j$ (Dnevnik ga bilježi mnogo češće nego Starčević), primjećujemo sljedeće.

Prvo, govor u saborskome dnevniku dosljedno je jekavski, a slogotvorno [r] pisano je jednoslovom $\langle r\rangle$, govor u knjižici dosljedno je ekavski, a slogotvorno [r] pisano je dvoslovom $\langle$ er $\rangle$. - Što sad da filolog o tom misli, kako je Starčević izgovarao jat i slogotvorno [r]?

Drugo, u knjižici stoga nalazimo očekivano ekavsko teraju (str. 5), tešio $(6,7)$, proterati (10), terati (11), ali - pazi sad - na tjedne pače na mesece (25). U saborskome pak dnevniku nalazimo očekivano jekavsko tjeraju (str. 142), tješio (143), protjerati (144), tjerati (144), ali - pazi sad - na ćedne, pače na mjesec (147, sic!, ne mjesece). - Što sad da filolog o tom misli, je li Starčević u Saboru rekao tedan, tjedan ili ćedan? Tim prije što pisanje tjedan imamo i u drugim ekavskim Starčevićevim tekstovima, primjerice nekoliko tjedanah (AS 1854:XXXV).

Treće, i dalje smo na jotaciji. U knjižici - tako i inače - Starčević bilježi izvestje (str. 3), najžestje (3), zdravje dopustjalo (10). U saborskome dnevniku imamo izviešće (str. 142), najžešće (142), zdravlje dopušćalo (144). - Što sad da filolog o tom misli, je li Starčević jednačio [sć] $\rightarrow$ [ść], a možemo slutiti da jest, je li izgovarao [zdravje] ili [zdravíe]? To samo opet i dodatno pokazuje koliko je promašena urednička odluka da se u ediciji Stoljeća hrvatske $k n j i z ̌ e v n o s t i$ umjesto $\langle\mathrm{dj}\rangle$ piše $\langle\mathrm{d}\rangle$, kao da o realnu izgovoru hrvatskih govornika u 19. stoljeću znamo sve, a zapravo znamo malo (usp. Marković 2018). To tim više što su u istome Jelčićevu izdanju (1995) zadržani autentični Starčevićevi dvoslovi $\langle\mathrm{tj}\rangle,\langle\mathrm{gj}\rangle,\langle$ àr $\rangle,\langle e r\rangle$ te jednoslov $\langle\mathrm{e}\rangle$, pa doista nije jasno komu je i zašto trn u oku bio nesretni dvoslov $\langle\mathrm{dj}\rangle$.

Četvrto, spominjali smo već aoriste glagola biti (usp. § IV.3). U saborskome dnevniku za 1. SG u gotovo istome odlomku imamo sedam puta $b i$ (AS 1866b [1867]:143). U knjižici pak na istome tom mjestu imamo tri puta bi i četiri puta bih (AS 1866a:6-7). - Što sad da filolog o tom misli, kako je Starčević izgovarao aoriste i kondicionale?

Peto, samo još nekoliko razlika. U saborskome dnevniku imamo politične stranke (str. 142), komparativ dulje (143), genitiv tih triuh (144). U knjižici imamo političke stranke (str. 4), duglje (7), tih trih (10). - Što sad da filolog o tom misli, koje je oblike Starčević rabio?

Nabrojenih pet detalja - doista su samo detalji - pokazuje koliko posla hrvatske filologe još čeka i koliko se treba kloniti samouvjerenih zaključaka o hrvatskome jeziku 19. stoljeća. 
VII. Starčevićeva idiosinkratična ekavština (usp. § II.3) - koja kajkavskoj i čakavskoj publici druge polovice 19. stoljeća zacijelo nije bila neobična kao što je nama danas - jezikoslovcima je zastrla pogled na cjelinu Starčevićeva jezika, čak toliko da nisu uočavali ni kasnije "pogreške" u samoj ekavštini, poput onih već spomenutih u popratnim tekstovima uz Istarski razvod (usp. § II.3) ili pojedinačnih oblika u Pismima Magjarolacah (AS 1879) poput smieli (I, str. 36), vidjelo (I, 39), uspiti (I, 121, umj. uspeti), nasliednike (II, 3), gdje (II, 57), pripovidiste (II, 72).

S druge strane, još od Mihovila Pavlinovića (usp. § III) ponavlja se fraza o osebujnosti Starčevićeva jezika, koja je s vremenom ispražnjena od bilo kakva sadržaja, jer se osim iznimno (npr. Jurišić 1943) nitko baš nije potrudio objasniti što je u tom jeziku bilo osebujno.

U ovome radu pokušali smo izdvojiti nekoliko odlika Starčevićeva jezika koje su suvremenicima doista mogle biti osebujne i objasniti zašto su to mogle biti. Sabrat ćemo zaključno one koje smatramo takvima; one s jedne strane mogu biti korisno forenzičko pomagalo pri određivanju autorstva anonimnih tekstova, s druge kao otklon upućivati na ono što je bio neutralan hrvatski književni jezik druge polovice 19. stoljeća.

Prvo, irealna kondicionalna rečenica sa $d a+b u d e m+$ GPR s prošlosnim ili pretprošlosnim značenjem (v. § IV.1):

Kako bi danas mi svi stajali, da budu Magjari tako učinili? (AS 1861c:32)

Drugo, anteriorna temporalna rečenica s veznikom kon što, također s veznikom nakon što, koji je tek bio ulazio u hrvatski jezik (v. § IV.5):

Napoleon I., kon što mu narod poveri svoju slavu i sreću znajući što je iniciativa, u svemu je lakše popustjao nego-li u njoj. (AS 1866a:8)

Treće, prijedložna skupina u supor 'usuprot, nasuprot' + DAT (v. § IV.6):

U supor svemu tomu, poznane našince nikako nemogosmo nametnuti. (AS 1879, I:3)

Četvrto, disjunktivno ali (v. § IV.7):

Uvrede ali svadju neka niko meni nepripisuje, [...] (AS 1852b:602)

Peto, futur budem + INF (v. § IV.10), koji je kao odlika Starčevićeva jezika već bio uočen, ali bez usporedbe s jezikom Starčevićevih suvremenika:

[...] ako se s Ungariom realno danas sdružimo, sutra se budemo s narodi Ungarie klati, prekosutra budemo skupa s onimi narodi jaukati pod štapom Austrie [...] (AS 1861c:37)

Pretpostavili smo također da je Starčevićevim suvremenicima stilogeno moglo biti anteriorno dok (v. § IV.4) te ponovili da je - koliko zasad znamo - Starčević u hrvatskome prvi svjesno stapao (v. § IV.12). Budućim istraži- 
vanjima Starčevićeva jezika naznačili smo daljnje moguće smjerove (v. §§ V-VI). Na njima je najzad da podupru ili opovrgnu sve ovdje rečeno.

\section{Citirana vrela i literatura}

Appendini, Francesco Maria. 1808. Grammatica della lingua Illirica. Ragusa: Presso Antonio Martechini.

ARj = Rječnik hrvatskoga ili srpskoga jezika. 1880-1976. Knj. I-XXIII. Zagreb: JAZU.

AS 1845 = Ante Starčević. 1845. Něšto o pirnih običajih u Lici. Danica horvatska, slavonska i dalmatinska, XI, 35 (30. VIII. 1845.), 140; 36 (6. IX. 1845.), 142-144; 37 (13. IX. 1845.), 145-147. [Pod pseudonimom anagramom A. V. Rastevčić.]

AS 1850 [1852] = Ante Starčević. 1850 [1852]. Predgovor + Objašnjenja [uz »Razvod istrianski od god. 1325.«]. Arkiv za pověstnicu jugoslavensku, II (1852), 2, 227-231 + 268-275. [Predgovor je datiran 18. VII. 1850.]

AS 1851a = Ante Starčević. 1851. Kolo. Članci za literaturu, umietnost i narodni život. Urednik Andria Torkvat Brlić. Knjiga VIII. [Prikaz]. Narodne novine, XVII, 227 (3. X. 1851.), 653-654. [Pod pseudonimom $\Sigma$.]

AS $1851 b=$ Ante Starčević. 1851. Dubrovnik. Cviet narodnoga književstva. Svezak drugi, za godinu MDCCL, urednik Matia Ban [Prikaz]. Narodne novine, XVII, 230 (7. X. 1851.), 661-662. [Pod pseudonimom $\Sigma$.]

AS 1851c $=$ Ante Starčević. 1851. Odgovor na poslanicu A. T. Brlića. Narodne novine, XVII, 239 (17. X. 1851.), 686-687; 242 (21. X. 1851.), 694-695. [Pod pseudonimom $\Sigma$.]

AS $1851 \mathrm{~d}=$ Ante Starčević. 1851 . Poziv k pretplati na »hervatsku rečoslovicu«. Narodne novine, XVII, 281 (6. XII. 1851.), 802.

AS 1852a = Ante Starčević. 1852. [Odgovor Sèrbskomu dnevniku]. Narodne novine, XVIII, 189 (18. VIII. 1852.), 511. [Anonimno, autorstvo objašnjeno u AS 1852b.]

AS 1852b = Ante Starčević. 1852. Odgovor Srbskome Dnevniku i beogradskim novinam. Narodne novine, XVIII, 224 (27. IX. 1852.), 602-603.

AS 1853 = Ante Starčević. 1853. Prizor iz života. Neven, II, 44 (3. XI. 1853.), 694-697; 45 (8. XI. 1853.), 711-717.

AS 1854 = Ante Starčević. 1854. Izjavljenje. Književna priloga $k » N e v e n u \ll$, III, 4 (13. VII. 1854.), XXXIV-XXXVI. [Datirano 16. VI. 1854.]

AS 1860 = Ante Starčević. 1860. Zajednica. Pozor, I, 33 (8. XI. 1860.), 67-68.

AS 1861a [1862] = Ante Starčević. 1861 [1862]. Govor u Hrvatskome saboru 15. V. 1861. Dnevnik sabora trojedne kraljevine Dalmacije, Hrvatske i Slavonije držana u glavnom gradu Zagrebu god. 1861. Zagreb: Brzotiskom Antuna Jakića, 92-93. 
AS 1861b [1893] = Ante Starčević. 1861 [1893]. Govor izrečen u hrvatskom saboru dne 15. svibnja 1861. Djela Dra. Ante Starčevića, knj. I. Govori. Zagreb: Tiskara Antuna Scholza. (pretisak Zagreb: Inačica, 1995), 7-8.

AS 1861c = Ante Starčević. 1861. Govor, što ga je u sednici sabora hervatskoga, na 26. lipnja 1861. o odnošenju Hervatske naprama Ungarii izustio Dr. Antun Starčević, poklisar kot. Grobničko-Hreljinskoga. Zagreb: Narodna tiskarnica Dra. Ljudevita Gaja.

AS 1861d [1862] = Ante Starčević. 1861 [1862]. Govor u Hrvatskome saboru 26. VI. 1861. Dnevnik sabora trojedne kraljevine Dalmacije, Hrvatske i Slavonije držana u glavnom gradu Zagrebu god. 1861. Zagreb: Brzotiskom Antuna Jakića, 276-383.

AS 1866a = Ante Starčević. 1866. Govor, što ga je izustio dr. Antun Starčević, zastupnik III. kotara grada Zagreba, u sednici sabora hervatskoga, na 27. sečnja 1866. Zagreb: Tiskom Dragutina Albrechta.

AS 1866b [1867] = Ante Starčević. 1866 [1867]. Govor u Hrvatskome saboru 27. I. 1866. Dnevnik sabora trojedne kraljevine Dalmacije, Hrvatske i Slavonije godine 1865/7. Zagreb: Brzotiskom Antuna Jakića, 142-147.

AS 1866c [1893] = Ante Starčević. 1866 [1893]. Govor izrečen u hrvatskom saboru dne 27. sečnja 1866. Djela Dra. Ante Starčevića, knj. I. Govori. Zagreb: Tiskara Antuna Scholza. (pretisak Zagreb: Inačica, 1995), 54-71.

AS 1867a = Ante Starčević. 1867. Stekliš i prostodušnik. Zvekan, I, 18 (1. X. 1867.), 98-102; 19 (15. X. 1867.), 110-113; 20 (1. XI. 1867.), 118-122. [Anonimno, samostalno objavljeno kao Bi-li k Slavstvu ili ka Hrvatstou? = AS 1867b.]

AS $1867 b$ = Ante Starčević. 1867. Bi-lik Slavstvu ili ka Hrvatstvu? Dva razgovora (Iz Zvekana.) Zagreb: Tiskom Dragutina Bokana.

AS 1867c [1894] = Ante Starčević. 1867 [1894]. Bi-li k Slavstvu ili ka Hrvatstvu? Dva razgovora. Djela Dra. Ante Starčevića, knj. III. Znanstveno-političke razprave. Zagreb: Tiskara Antuna Scholza. (pretisak Zagreb: Inačica, 1995), 3-47.

AS 1867d = Ante Starčević. 1867. Oklad. Zvekan, I, 20 (1. XI. 1867.), 122-124. [Anonimno, poslije "Uvod” u Pisma Magjarolacah = AS 1879.]

AS 1870 = Ante Starčević. 1870. Nekolike uspomene. Zagreb: Tisak narodne tiskare.

AS 1871a = Ante Starčević. 1871. Jezik i pismo Hervatah. Hervatska, I, 1 (1. I. 1871.), 1-2.

AS $1871 b=$ Ante Starčević. 1871. Govor u Krapinskim Toplicama 20. V. 1871. Hervatska, I, 22 (28. V. 1871.), 2-3.

AS $1876=$ Ante Starčević. 1876. Pasmina slavoserbska po Hervatskoj. Zagreb: Tisak Lav. Hartmana i družbe.

AS 1878 = Ante Starčević. 1878. Govor o adresi većine i nacert adrese posebne od 
Dra A. Starčevića poklisara kraljevičkoga. Zagreb: Slova Dioničke tiskare. AS $1879=$ Ante Starčević. 1879. Pisma Magjarolacah. Del I-II. (pretisak) Zagreb: Inačica, 1995.

AS 1881a [1893] = Ante Starčević. 1881 [1893]. Govor izrečen u hrvatskom saboru 8. srpnja 1881. Djela Dra. Ante Starčevića, knj. I. Govori. Zagreb: Tiskara Antuna Scholza. (pretisak Zagreb: Inačica, 1995), 172-180.

AS 1888 = Ante Starčević. 1888. Govor o zakonskoj osnovi zadrugah Dr. A. Starčevića zastupnika naroda u saborskoj sednici od 20. studenoga 1888. Zagreb: Tiskara Scholz i Kralja.

AS 1889 = Ante Starčević. 1889. Ustavi Francezke. (pretisak) Zagreb: Inačica, 1995.

AS 1890 = Ante Starčević. 1890. Govori Dr. Ante Starčevića i grofa Khuen-Hedervarija u sjednici saborskoj od 18. studena 1890. o komasaciji. Preštampano iz »Hervatske«. Zagreb: Tiskara Scholz i Kralja (A. Scholz).

Babukić, Vjekoslav [Věkoslav]. 1854. Ilirska slovnica. Zagreb: Bèrzotiskom nar. tiskarnice Dra. Ljudevit Gaja.

Barišić, Pavo. 1994. Starčevićeva politička retorika. Prilozi za istraživanje hrvatske filozofske baštine, 20, 1-2 (39-40), 217-242.

Bečki dogovor 1850 = Književni dogovor [28. III. 1850.]. Narodne novine, XVI, 76 (3. IV. 1850.), 1.

Bratulić, Josip. 1995. Ante Starčević. Djela Dra. Ante Starčevića, knj. III. Znanstveno-političke razprave. Zagreb: Inačica, 469-484.

Budmani, Pietro. 1867. Grammatica della lingua serbo-croata (illirica). Vienna: A spese dell' autore.

Della Bella, Ardelio. 1728 [2006]. Istruzioni grammaticali della lingua illirica (pretisak). Prev. Nives Sironić-Bonefačić. Zagreb: Institut za hrvatski jezik i jezikoslovlje.

Drechsler, Branko. 1912. Dr. Ante Starčević: Književna studija iz doba apsolutizma Bachova. Hrvatsko kolo, VII, 355-408.

EK 1893 = Evgenij Kumičić. s. a. (?1893). Urota zrinsko frankopanska. Preštampano iz Doma i svieta. Sv. I-III. Zagreb: Tisak i naklada knjižare Lav. Hartmana (Kugli \& Deutsch).

EK 1895 = Evgenij Kumičić. s. a. (?1895). Urota zrinsko-frankopanska. Drugo izdanje. Zagreb: Tisak i naklada knjižare L. Hartmana (Kugli i Deutsch).

Holjevac, Željko. 1999. Jezik i nacija u hrvatskim i srpskim nacionalnim ideologijama: Starčevićeva polemika iz 1852. godine. Migracijske teme, $15,3,289-321$.

Horvat, Josip. 1940. Ante Starčević: Kulturno-povijesna slika. Zagreb: Naklada Antuna Velzeka. 
Jelčić, Dubravko. 1995. Predgovor + Kronologija života Ante Starčevića. Ante Starčević: Književna djela [Stoljeća hrvatske književnosti]. Zagreb: Matica hrvatska, 1-36.

Jurišić, Blaž. 1943. Pogovor. Ante Starčević: Izabrani spisi. Prir. Jurišić, Blaž. Zagreb: Izdanje Hrvatskog izdavalačkog bibliografskog zavoda, 515558.

Karadžić, Vuk Stefanović [B. C. K.]. 1849. Srbi svi i svuda. Kovčežić za istoriju, jezik i običaje Srba sva tri zakona. Beč: Štamparija Jermenskoga manastira, 1-27.

Katičić, Radoslav. 1986. Sintaksa hrvatskoga knjižeonog jezika: Nacrt za gramatiku. Zagreb: JAZU - Globus.

KRj = Rječnik hrvatskoga kajkavskoga književnog jezika. 1984-1976. Sv. 1-13: A-Razbor. Zagreb: HAZU - IHJJ.

Ladan, Tomislav. 1971. Ante Starčević + O ovom izboru. Ante Starčević: Politički spisi. Zagreb: Znanje, 5-75; 591-592.

Maretić, Tomo. 1899. Gramatika i stilistika hrvatskoga ili srpskoga knjižeonog jezika. Zagreb: Štampa i naklada knjižare L. Hartmana (Kugli i Deutsch).

Maretić, Tomo. 1924. Hrvatski ili srpski jezični savjetnik za sve one, koji žele dobro govoriti i pisati književnim našim jezikom: Dopuna Broz-Ivekovićevu Rječniku hrvatskoga jezika. Zagreb: JAZU.

Marković, Ivan. 2016. Od Oca do Ćaće: 150 godina hrvatskih stopljenica. Marković, Ivan; Ivana Klindić; Iva Borković. Hrvatski rječnik stopljenica. Zagreb: Filozofski fakultet Sveučilišta u Zagrebu - Odsjek za kroatisti$\mathrm{ku}$ - Katedra za stilistiku. http://stilistika.org/od-oca-do-cace

Marković, Ivan. 2018. O britkosti: Filološko paljetkovanje po 2017. Zagreb: Stilistika.org - Filozofski fakultet Sveučilišta u Zagrebu - Odsjek za kroatistiku - Katedra za stilistiku. http://stilistika.org/ivan-markovic-o-britkosti

Mažuranić, Antun. 1859. Slovnica Hèrvatska: Za gimnazije i realne škole. Dio I. Rěčoslovje. Zagreb: Troškom spisateljevim.

Moguš, Milan. 1997. Starčevićevi pogledi na hrvatski jezik. Ante Starčević i njegovo djelo. Zbornik radova / Znanstveni skup o 100. obljetnici smrti Oca domovine 18. i 19. travnja u Zagrebu. Ur. Jelčić, Dubravko; Tomislav Sabljak. Zagreb: Hrvatska akademija znanosti i umjetnosti, 143-150.

MP 1876 = Mihovil Pavlinović. 1876. Razgovor o Slavenstvu, Jugoslavenstvu, Srbo-Hrvatstou. Treće, popravljeno i popunjeno izdanje. Zadar: Brzotiskom Narodnoga lista.

Musić, August. 1896. Kondicional u hrvatskom jeziku. Rad JAZU, 127, 141-209.

Musić, August. 1900. Rečenice s konjunkcijom »da« u hrvatskom jeziku. Rad JAZU, 142, 1-125. 
Sabljak, Tomislav. 1997. Jezik paradoksa u Starčevićevoj prozi. Ante Starčević i njegovo djelo. Zbornik radova / Znanstveni skup o 100. obljetnici smrti Oca domovine 18. i 19. travnja u Zagrebu. Ur. Jelčić, Dubravko; Tomislav Sabljak. Zagreb: Hrvatska akademija znanosti i umjetnosti, 151-154.

Samardžija, Marko. 2017. Starčevićev jezični paradoks. Ante Starčević. Zbornik radova sa znanstvenog kolokvija u povodu 120. godišnjice smrti. Ur. Matković, Stjepan; Božidar Petrač. Zagreb: Društvo hrvatskih književnika, 129-142.

SD 1861 [1862] = Dnevnik sabora trojedne kraljevine Dalmacije, Hrvatske i Slavonije držana u glavnom gradu Zagrebu god. 1861. Zagreb: Brzotiskom Antuna Jakića.

SD 1865-1867 = Dnevnik sabora trojedne kraljevine Dalmacije, Hroatske i Slavonije godine 1865/7. Zagreb: Brzotiskom Antuna Jakića.

SD 1868-1871 = Dnevnik sabora trojedne kraljevine Dalmacije, Hrvatske i Slavonije držana u glavnom gradu Zagrebu godine 1868.-1871. Zagreb: Tiskara »Narodnih novina $«$.

SD 1872-1875 = Saborski dnevnik kraljevinah Hrvatske, Slavonije i Dalmacije god. 1872/5. Svezak I. Zagreb: Tiskara Lav. Hartmana i družbe.

SD 1878-1881 [1903] = Saborski dnevnik kraljevinah Hrvatske, Slavonije i Dalmacije god. 1878-1881. Dio I. Zagreb: Tisak Kr. zemaljske tiskare.

SD 1884-1887 = Saborski dnevnik kraljevinah Hrvatske, Slavonije $i$ Dalmacije godina 1884-1887. Svezak I. Zagreb: Tiskarski zavod »Narodnih novinah $\ll$.

Silić, Josip; Ivo Pranjković. 2005. Gramatika hrvatskoga jezika za gimnazije i visoka učilišta. Zagreb: Školska knjiga.

Slavić, Dean. 2017. Retorika i stil Starčevićevih govora. Ante Starčević. Zbornik radova sa znanstvenog kolokvija u povodu 120. godišnjice smrti. Ur. Matković, Stjepan; Božidar Petrač. Zagreb: Društvo hrvatskih književnika, 143-168.

Starčević, Šime [Shíme Starcsevich]. 1812. Nòvà ricsôslovica ilìricskà. Trst: Slovima Gaspara Weis.

Šegvić, Kerubin. 1911. Dr. Ante Starčević: Njegov život i njegova djela. Zagreb: Tiskara Hrvatske stranke prava d. d.

Šimić, Stanislav. 1936. Starčevićev stil. Dr. Ante Starčević: O 40. godišnjici smrti. Zagreb: Naklada »Pramatica K. D.«, 69-75.

Škreb, Zdenko. 1949. Značenje igre riječima. Rad JAZU, 278, 77-193.

Tafra, Branka. 1995. Jesu li ahavci izgovarali $h$ ? Jezikoslovna razdvojba. Zagreb: Matica hrvatska, 109-130.

Veber [Weber], Adolfo. 1859. Skladnja ilirskoga jezika za niže gimnazije. Beč: C. k. naklada školskih knjiga. 
Veber, Adolfo. 1873. Slovnica hèrvatska za srednja učilišta. Beč: Troškom spisateljevim.

Vince, Zlatko. 1978 [2002]. Putovima hrvatskoga književnog jezika: Lingvističko-kulturnopovijesni prikaz filoloških škola i njihovih izvora (treće, dopunjeno izdanje). Zagreb: Nakladni zavod MH.

\title{
Notes on Ante Starčević's language
}

\begin{abstract}
The language of Ante Starčević (1823-1896), an extremely important Croatian politician and writer, was considered as "peculiar" even by Starčević's contemporaries (e.g. Mihovil Pavlinović). However, little has been said about this peculiarity by Croatian linguists except the fact that since 1850. Starčević consistently wrote Ecavian, literary Croatian in the second half of the 19th century being Jekavian. In the paper several features of Starčević's language are recognized and analyzed which might have been "peculiar" to his contemporaries. These are (1) unreal conditional clause with the conjunction $d a+b u d e m$ (perfect present of biti 'to be') + active participle, (2) anterior temporal clause with the conjunction kon što or nakon što 'after which', (3) prepositional phrase $u$ supor 'as opposed to, conversely' (+ dative), (4) disjunctive use of the conjunction ali 'but', and (5) future tense formed by budem + infinitive.

Ključne riječi: hrvatski jezik, 19. stoljeće, sintaksa, veznici, konjugacija, Ante Starčević
\end{abstract}

Keywords: Croatian, 19th century, syntax, conjunctions, conjugation, Ante Starčević 